\title{
Radiochemical Analyses of Soil and Vegetation Samples Taken from the Hanford Environs, 1971-1976
}

by

M. L. Miller

J. J. Fix

P. E. Bramson

June 1977

Prepared for the Energy Research and Development Administration under Contract EY-76-C-06-1830 


\section{NOTICE}

This report was prepared as an account of work sponsored by the United States Covernment. Neither the United States nor the Energy Research and Development Administration, nor any of their employees, nor any of their contractors, subcontractors, or their employees, makes any warranty, express or implied, or assumes any legal liability or responsibility for the accuracy, completeness or usefulness of any information, apparatus, product or process diselosed, or represents that its use would not infringe privately owned rights.

PACIFIC NORTHWEST LABORATORY

operated by

BATTELLE

for the

ENERCY RESEARCH AND DEVELOPMENT ADMINISTRATION

Under Coneract EY-76-C-06-1830

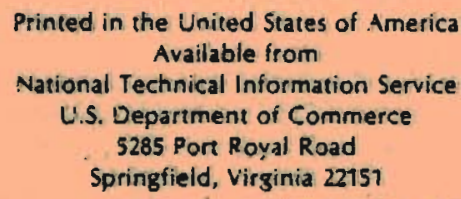

Price: Printed Copy ___ Microfiche $\$ 3.00$

$\begin{array}{lc}\text {-Pages } & \begin{array}{c}\text { NTIS } \\ \text { Selling Price }\end{array} \\ 001-025 & \$ 4.50 \\ 025-050 & \$ 5.00 \\ 051-075 & \$ 5.50 \\ 076-100 & \$ 6.00 \\ 107-125 & \$ 6.50 \\ 126-150 & \$ 7.00 \\ 151-175 & \$ 7.75 \\ 176-200 & \$ 8.50 \\ 201-225 & \$ 8.75 \\ 226-250 & \$ 9.00 \\ 251-275 & \$ 10.00 \\ 275-300 & \$ 10.25\end{array}$


BNWL-2249

33679000526741

UC -41

RADIOCHEMICAL ANALYSES OF SOIL AND VEGETATION SAMPLES TAKEN FROM THE HANFORD ENVIRONS, 1971-1976

by

M. L. Miller

J. J. Fix

P. E. Bramson

June 1977

BATTELLE

Pacific Northwest Laboratories

Richland, WA 99352 


\section{CONTENTS}

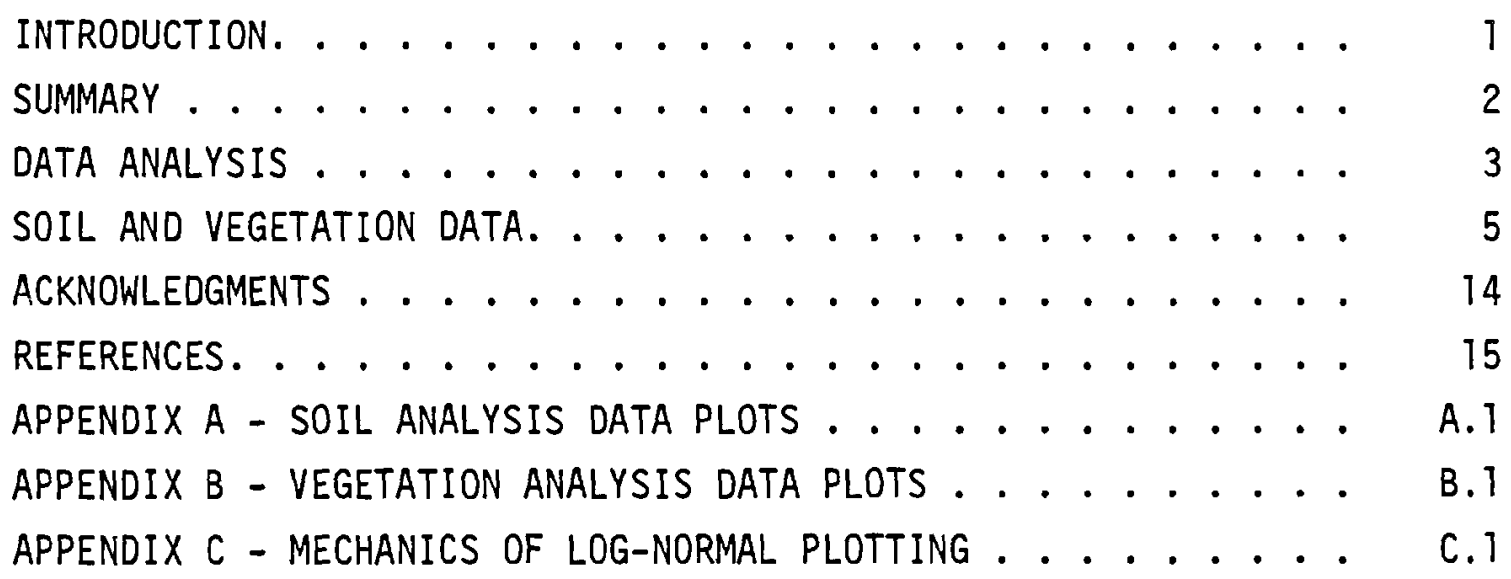




\section{RADIOCHEMICAL ANALYSES OF SOIL AND VEGETATION SAMPLES}

TAKEN FROM THE HANFORD ENVIRONS, 1971-1976

\section{INTRODUCTION}

As part of the Environmental Surveillance Program for the Hanford Project, surface soil and vegetation samples have been routinely collected from locations on the site, as well as several perimeter locations. The soil data represent a means of assessing the deposition of radionuclides during each year and, with time, of assessing any cumulative buildup of radionuclides. Once deposited on soil or vegetation, the radionuclides can potentially contribute to the population dose through a variety of environmental pathways including external radiation, inhalation of resuspended activity, ingestion of edible vegetation, as well as ingestion of meat and milk products obtained from livestock pastured on contaminated pasture.

Samples of soil and vegetation were analyzed radiochemically to assess the relative concentrations of the radionuclides, both those potentialiy originating from Hanford operations and those already present in the environment due to worldwide fallout or natural causes. The resulting data were evaluated using probability plotting, which provided a visual estimate of the similarity of radionuclide concentrations observed at the many different locations sampled. If the radionuclide concentrations were similar at a 11 locations, the radionuclide's presence was attributed to worldwide fallout or natural causes. If a few locations showed radionuclide concentrations greater than expected from the concentrations observed at the many other locations, these locations and associated radionuclide concentrations were evaluated further to determine if Hanford facilities were responsible for the increase.

Appendix A contains the plots of soil data, beginning with naturallyoccurring radionuclides in order of increasing atomic number and ending with man-made radionuclides in order of iricreasing atomic number. The same arrangement is used in Appendix $B$, which contains vegetation data plots. Appendix $C$ contains a detailed description of the mechanics of log-normal plotting. 


\section{SUMMARY}

Soil and vegetation have routinely been collected on the Hanford Site and surrounding environs as one method of monitoring radionuclide concentrations potentially attributable to Hanford operations. (3) With the exception of a few locations, the data indicate that Hanford operations have made no significant contribution to existing radionuclide concentrations in soil and vegetation. Most of the activity seen in the samples can be attributed to natural causes or worldwide atmospheric fallout. The few locations apparently impacted by Hanford operations were:

- east of the California Nuclear burial site, which showed elevated levels of ${ }^{60} \mathrm{Co}$ in soil and vegetation

- northeast of the 1301-N trench, which showed elevated levels of ${ }^{54} \mathrm{Mn},{ }^{60} \mathrm{Co}$, and ${ }^{134} \mathrm{Cs}$ in soil and ${ }^{60} \mathrm{Co}$ in vegetation

- Columbia River island at river mile 340 (near North Richland), which showed elevated levels of ${ }^{60} \mathrm{Co}$

- east of 200 West Area, which showed elevated levels of $\mathrm{Pu}$ in soil.

The concentrations of naturally-occurring radionuclides measured are consistent with values listed in NCRP Report \#45, "Natural Background Radiation in the United States", (1) and the Washington State Annual Environmental Radiation Surveillance Reports. (2) 


\section{DATA ANALYSIS}

The data in this report are presented in the form of log-normal probability plots. Such plots are useful tools for conveniently cataloguing large amounts of data, as well as providing a first approximation of the similarity of the data. The basis for using log-normal plotting is basically experience which has shown that large numbers of nuclide/media combinations yield a straight line when plotted on log-probability paper. Because the data are represented graphically, the mean, standard deviation, expected upper limits, and any abnormalities in the data can readily be determined visually. (4)

Characteristics of special importance in the use of log-normal plots are linearity (denoting data from a common population), standard geometric deviation $\left(\sigma_{g}\right)$ (an indicator of variability or range), and geometric mean $\left(x_{g}\right)$. The values for $\sigma_{g}$ and $x_{g}$ can be obtained from the graphs by the ratio of the $84 \% / 50 \%$ intercepts and the $50 \%$ intercept, respectively. These intercepts are indicated on many of the graphs for the convenience of the reader. Linearity of a graph implies that any Hanford contribution to the radionuclide concentrations is indistinguishable from regional levels of worldwide fallout or natural radioactivity. Detectable Hanford contributions to the observed radioactivity must necessarily occur at a higher concentration than would be expected from fallout or natural causes.

Wherever a particular radionuclide concentration appears elevated (on the log-normal plots) compared to the expected concentration based on the concentrations observed at other locations, additional investigation to determine if Hanford operations are responsible include the following:

- What is the geographical location of the sample site? Is there a detectable pattern (downwind) to the abnormal observation or is the sample(s) from an area in close proximity to a facility which has the potential for release of the radionuclide?

- Does the location of the sample(s) show elevated levels for other radionuclides or for more than one analysis? 
- If several locations appear elevated, what year were the samples collected? Were regional levels of deposition of fallout radionuclides higher for that year?

For the purpose of this publication, only the plots of the statistical$1 y$ positive data will be shown. This means of reporting is informative without being cumbersome and voluminous. Interpretations and explanations of abnormal data that are shown will be stressed to provide sufficient information to the reader. Only data that lies above the approximate detection limit (ADL) is plotted. The ADL is defined as the 2-sigma counting uncertainty and may vary, depending on sample mass, counting time used, or in the case of gamma spectroscopy, the interference of other radionuclides. that may be present.

Appendix A contains plots of soil data, beginning with naturallyoccurring radionuclides in order of increasing atomic number and ending with man-made radionuclides in order of increasing atomic number. The same arrangement is used for Appendix $B$, which contains vegetation data plots. Appendix $C$ describes the mechanics of log-normal plotting. 
SOIL AND VEGETATION DATA

During the years 1971 through 1976, 136 soil and vegetation samples were collected from the Hanford environs. These locations are shown in Figure 1; the description of each location and years sampled are shown in Table 1. Several locations were sampled during each year. Each soil sample analyzed was a composite of 5 "plugs" of soil collected from an area approximately 10 meters square. Each plug was about 2.5 centimeters in depth and 10 centimeters in diameter. Samples of perennial vegetation, primarily the growth from rabbit brush plants, were collected from the immediate vicinity of each soil sampling location. Both sets of data were analyzed for gamma-emitting radionuclides using a lithium-drifted germanium detector, for plutonium nuclides using alpha spectroscopy, and for uranium and ${ }^{\circ} \mathrm{OSr}$ by specific analysis.

\section{NATURALLY-OCCURRING RADIONUCLIDES}

Figures 2 and 3 show log-normal probability plots of naturally-occurring ${ }^{40} \mathrm{~K},{ }^{224} \mathrm{Ra},{ }^{226} \mathrm{Ra}$ and $U$ in soil, as well as ${ }^{40} \mathrm{~K}$ and $U$ in vegetation. It is apparent from the linearity of the data in the figures that the data are represented very well by a log-normal plot. Potassium-40 is present in the highest concentrations at all locations in both soil and vegetation. The radium isotopes were generally less-than detectible in the vegetation samples. A single result, $7.2 \mathrm{pCi} / \mathrm{g}$, for uranium in vegetation was much greater than expected. This particular result was for the Byers Landing sampling location (map No. 7A) during 1974. The value is likely in error since all previous and subsequent samples have shown concentrations of $U$ similar to everywhere else. Table 2 summarizes the median concentration of the naturally-occurring radionuclides observed in soil and vegetation. Appendices $A$ and $B$ contain plots for each individual radionuclide. 


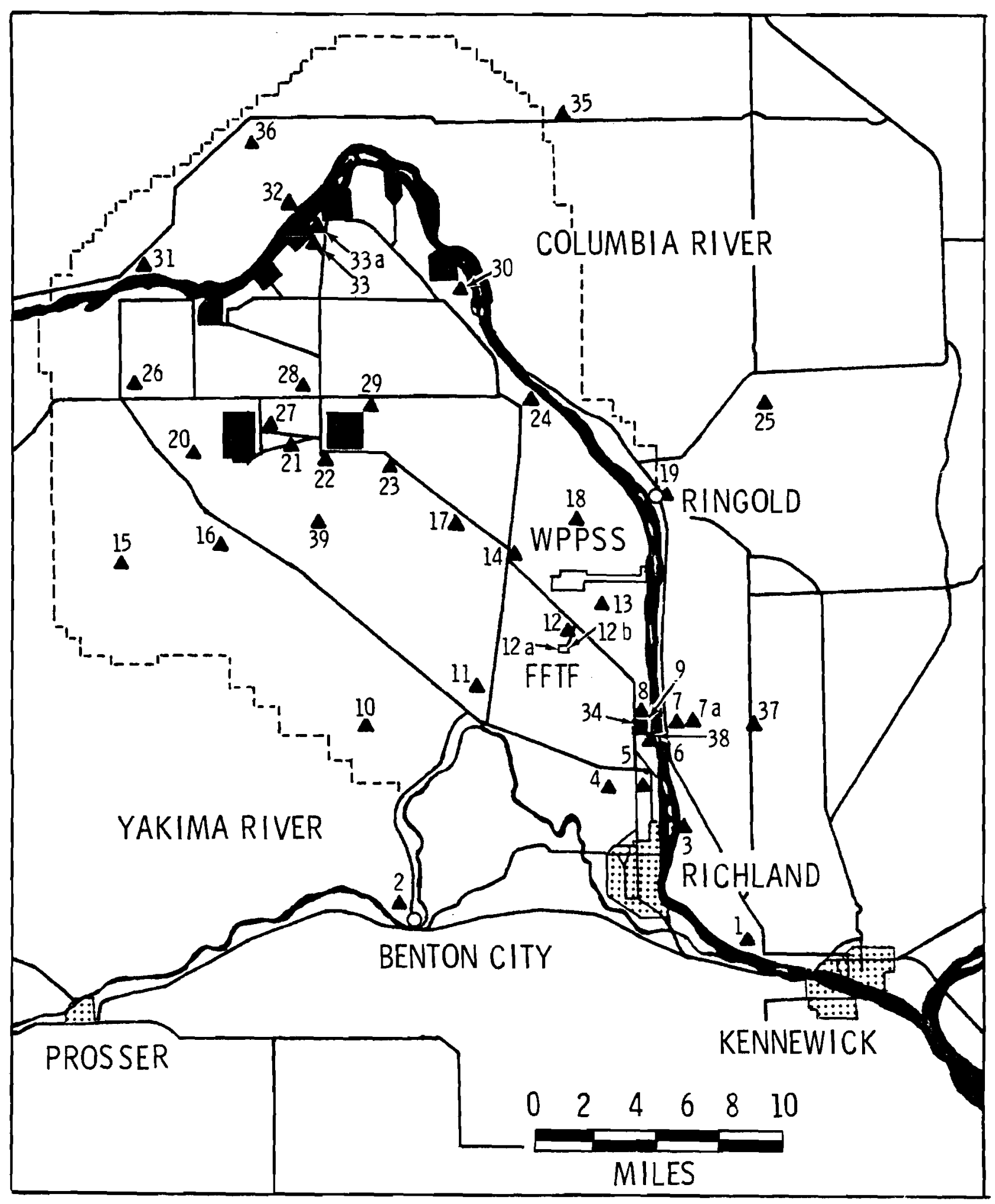

FIGURE 1. Hanford Environs Soil and

Vegetation Sampling Locations 


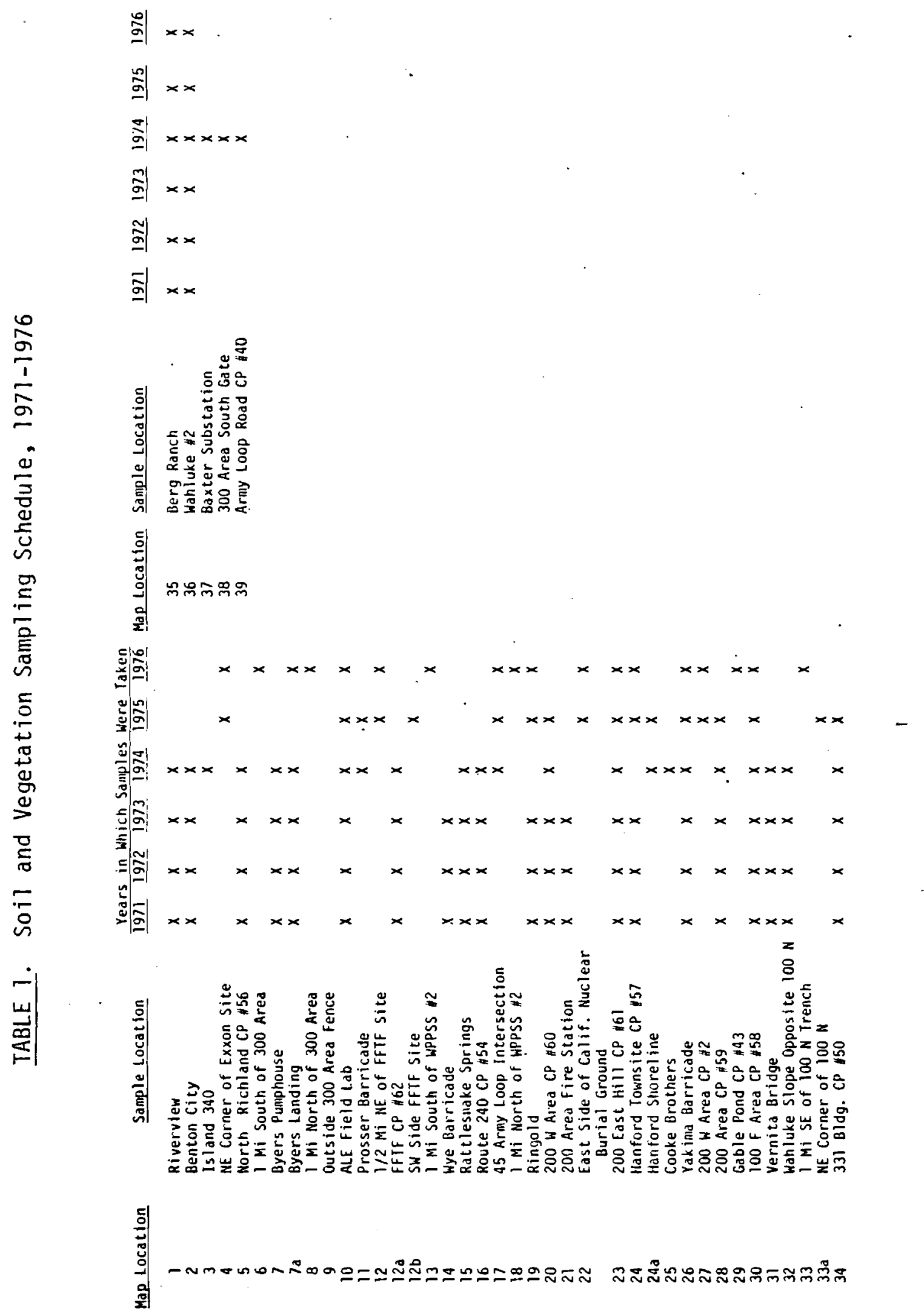


FIGURE 2. Naturally-Occurring Radionuclides in Soil

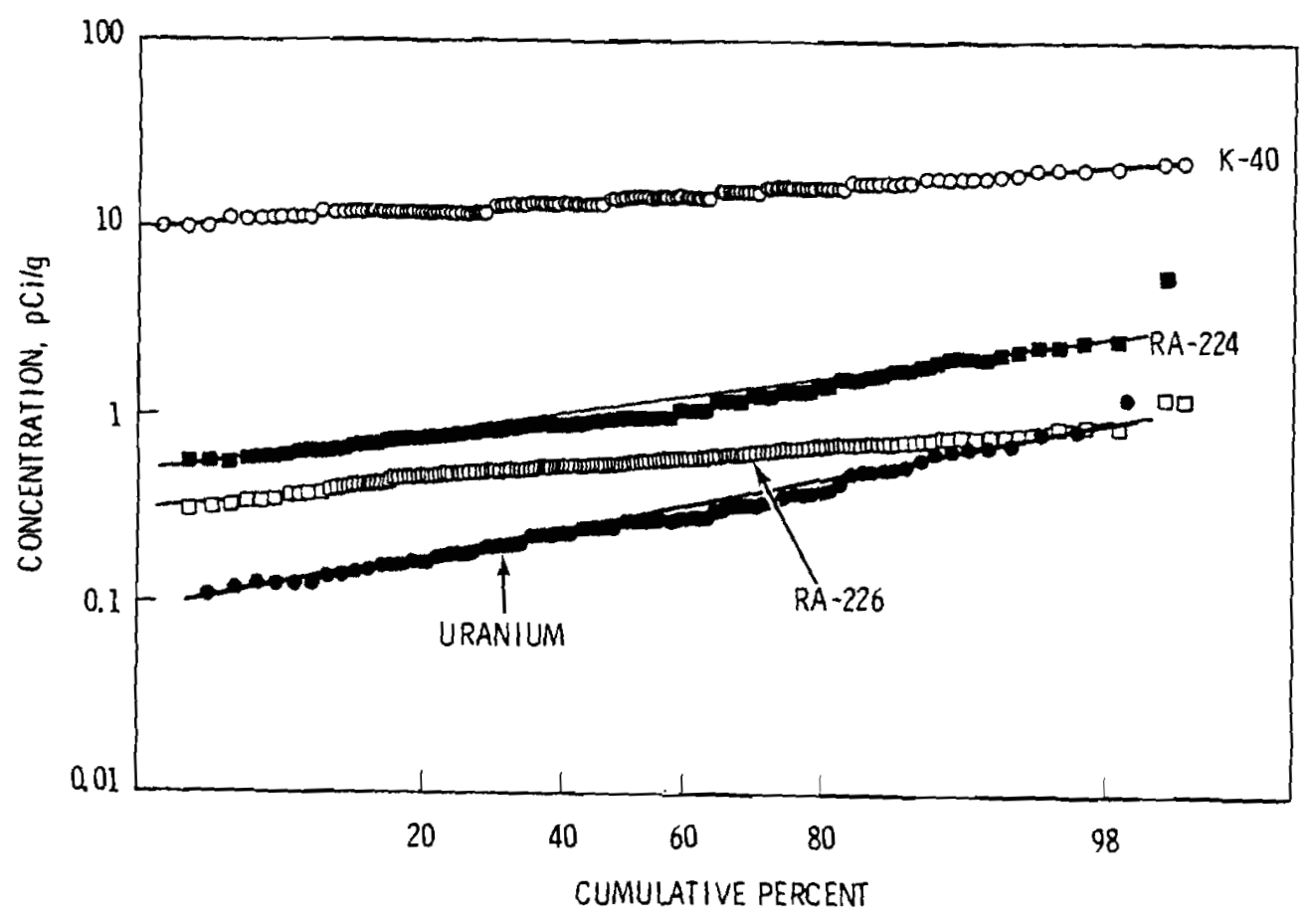

FIGURE 3. Naturally-Occurring Radionuclides in Vegetation

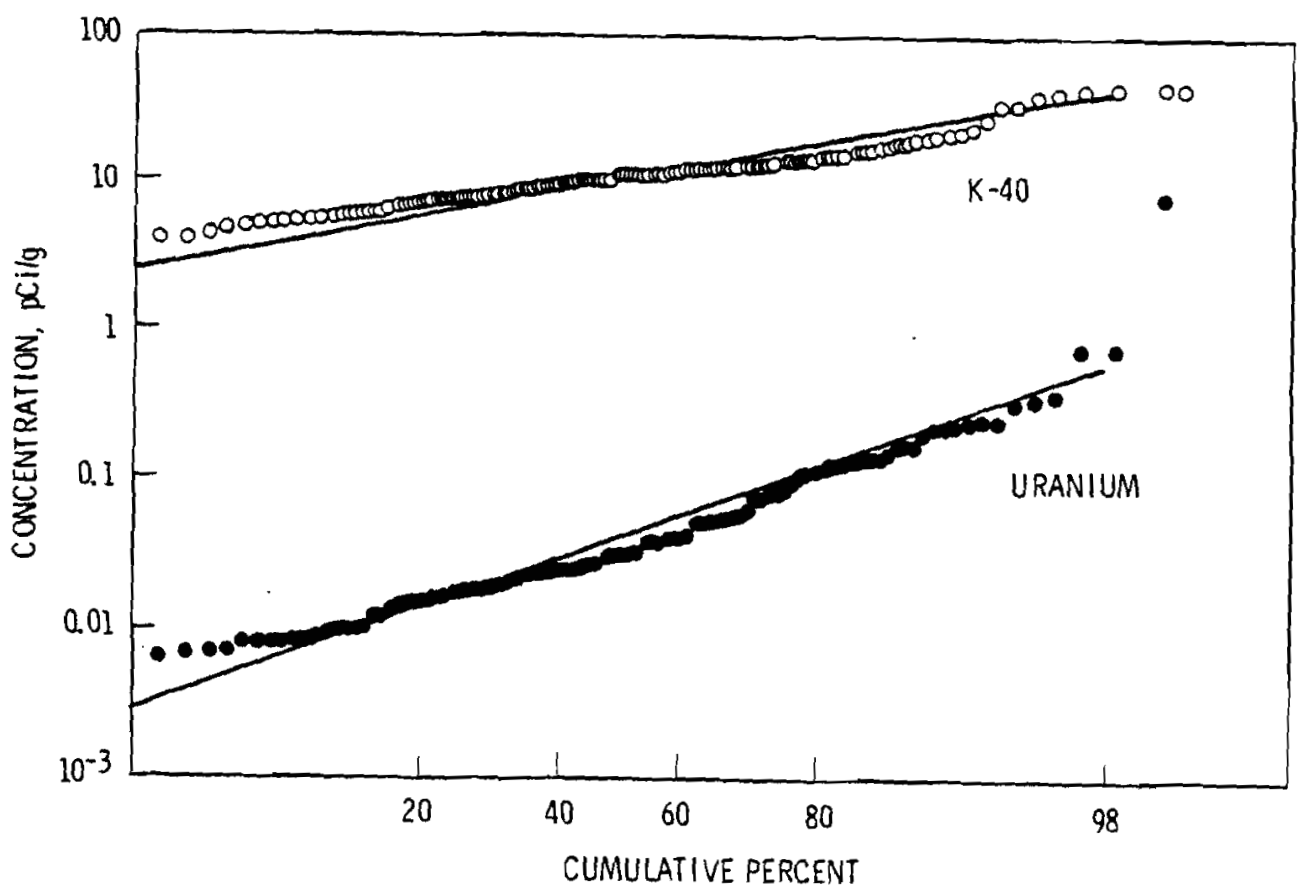


TABLE 2. Naturally-Occurring Radionuclides

in Soil and Vegetation

\begin{tabular}{cccc} 
& \multicolumn{2}{c}{ Median Concentration $(\mathrm{pCi} / \mathrm{g})$ (Dry Weight) } \\
${ }^{40 \mathrm{~K}}$ & $\frac{\text { Soji }}{15}$ & $\frac{\text { Vegetation }}{11}$ \\
${ }^{22} \mathrm{Ra}$ & & 1.1 & -- \\
$\mathrm{U}$ & 0.6 & -- \\
$\mathrm{U}$ & & 0.3 & 0.03
\end{tabular}

MAN-MADE RADIONUCLIDES

Several radionuclides from fallout debris in the atmosphere are routinely measured in soil and vegetation samples. Distinguishable Hanford contributions to the observed activity must be sufficiently elevated to be separable from the variability observed in the fallout radionuclide concentrations. Figures 4 and 5 show the concentrations of ${ }^{90} \mathrm{Sr},{ }^{137} \mathrm{Cs}$, $238 \mathrm{Pu}$ and 239-240Pu in soil and vegetation. It is apparent that the data for each radionuclide are well represented by the log-normal plots. The observed concentrations are attributed to fallout with the possible exception of the uppermost $239-240 \mathrm{Pu}$ concentration, $0.3 \mathrm{pCi} / \mathrm{g}$, in soil. This point represents the analysis of a soll sample collected east of the 200 West Area (map location \#27). The observed concentration is slightly higher than would be expected from fallout based on the samples collected everywhere else.

The uppermost ${ }^{137} \mathrm{Cs}$ point for vegetation represents the analysis of a sample collected from map location number 20 during 1972. Although the point appears to be elevated, the activity is attributed to either fallout, vegetation variety collected, or even to an analytical error since the soil samples collected at this location during the years 1971-1975 (Table 1) did not show elevated levels of ${ }^{137} \mathrm{Cs}$ as shown in Figure 4.

A few locations were apparently impacted by Hanford operations. Map location \#33a, which is near the NE corner of the 1301-N trench, showed elevated levels of ${ }^{54} \mathrm{Mn},{ }^{60} \mathrm{Co}$, and ${ }^{134} \mathrm{Cs}$ during 1975. Map location \#3, which is on an island in North Richland (river mile 340), shows elevated 
FIGURE 4. Man-Made Radionuclides in Soil

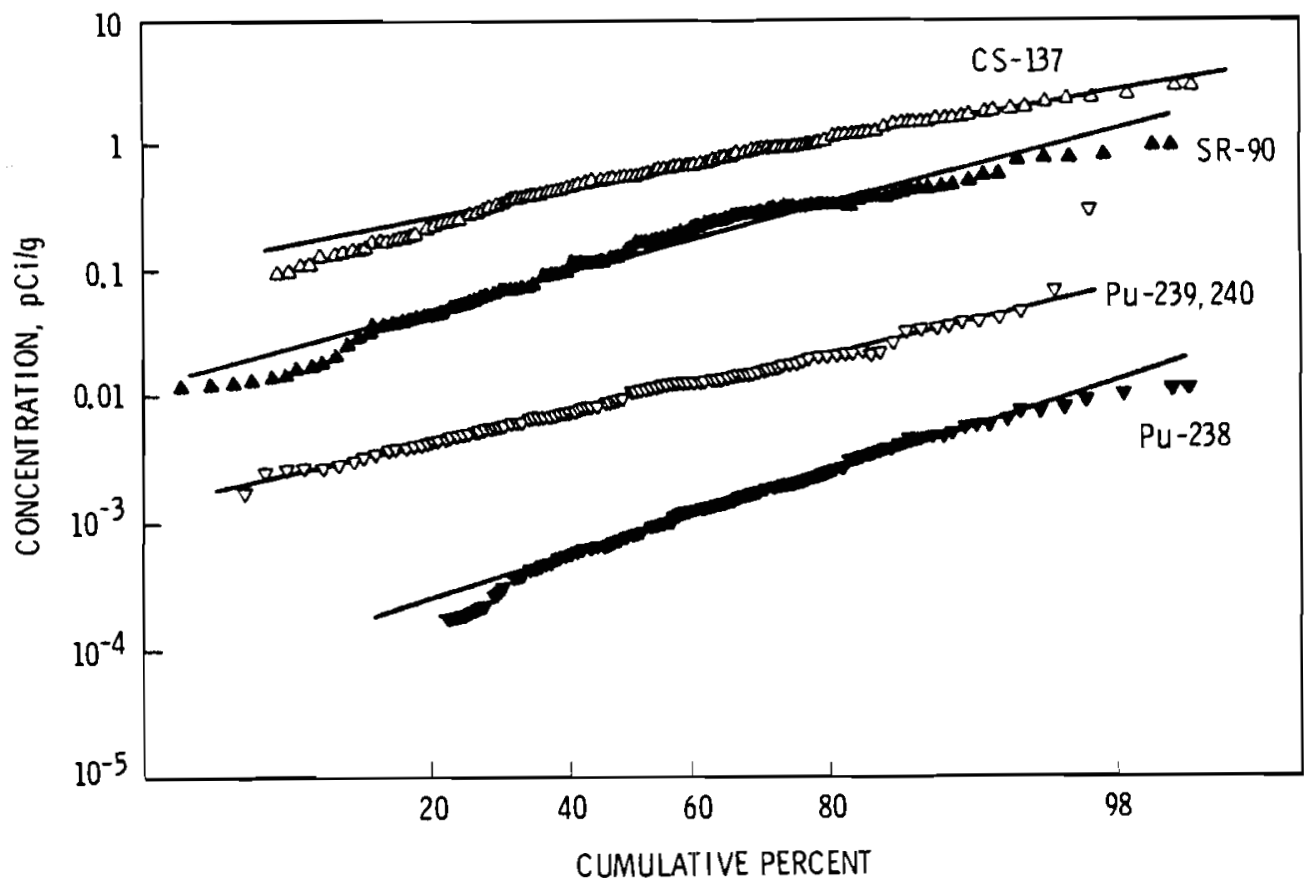

FIGURE 5. Man-Made Radionuclides in Vegetation

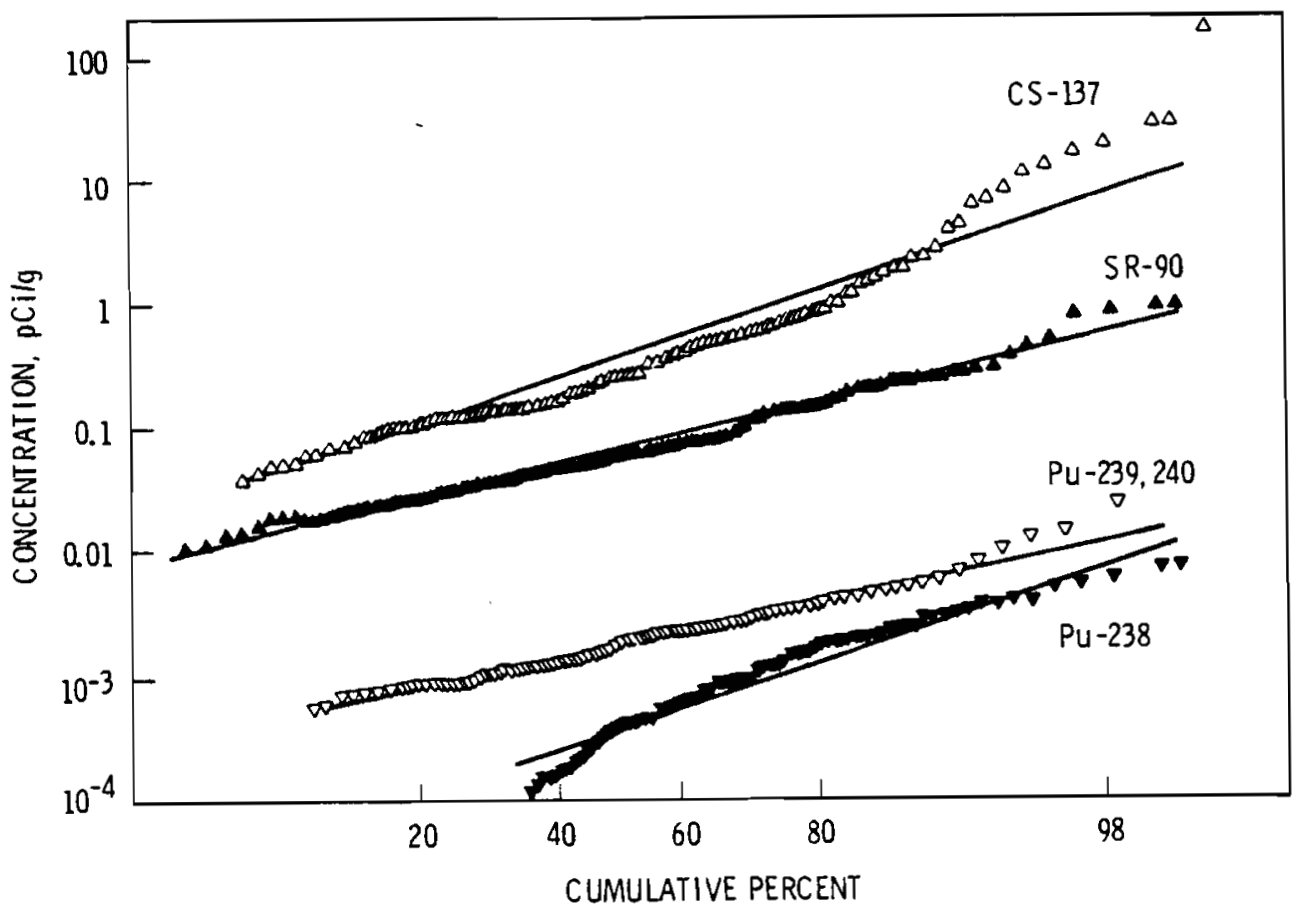


levels of ${ }^{60} \mathrm{Co}$ consistent with past analyses which show elevated levels of ${ }^{60} \mathrm{Co}$ along the Columbia River island, shoreline and slough areas. (6) Also, map location \#22, which is on the east side of the California Nuclear burial ground shows slightly elevated ${ }^{60}$ Co levels. Figure 6 shows lognormal plots of the ${ }^{54} \mathrm{Mn},{ }^{60} \mathrm{Co}$ and ${ }^{134} \mathrm{Cs}$ data. The uppermost point for ${ }^{54} \mathrm{Mn}$ and ${ }^{134} \mathrm{Cs}$ and the second to the highest ${ }^{60} \mathrm{Co}$ point represent the soil sample collected NE of the $1301-\mathrm{N}$ trench. The uppermost ${ }^{\circ} \mathrm{Co}$ point is for the Columbia River island location. The third highest ${ }^{60} \mathrm{Co}$ concentration is for the location east of the California Nuclear burial ground.

FIGURE 6. Man-Made Radionuclides in Soil

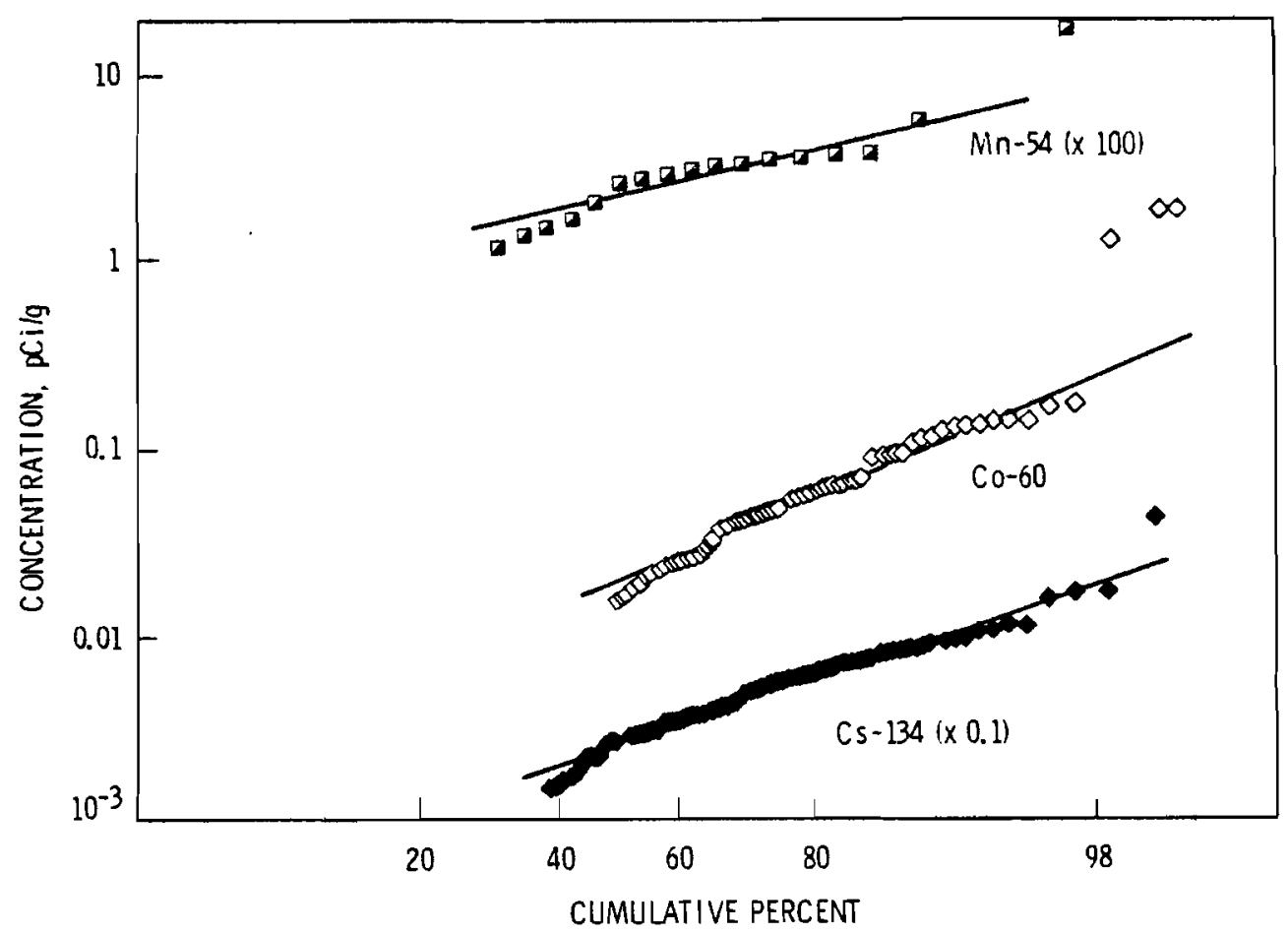


For vegetation samples, only ${ }^{60} \mathrm{Co}$ concentrations at a few locations were apparently elevated. Figure 7 is a log-normal plot of the ${ }^{60} \mathrm{Co}$ results. The uppermost three points all are greater than expected based on the data for the other locations. These results are $3.4 \mathrm{pCi} / \mathrm{g}$ from near the NE corner of the 1301-N trench (map location \#33A), $2.1 \mathrm{pCi} / \mathrm{g}$ from the east side of the California Nuclear burial ground (map location \#22) and $0.9 \mathrm{pCi} / \mathrm{g}$ from near Gable Mountain Pond (map location \#29). These locations, with the exception of the Gable Mountain Pond location, also showed elevated ${ }^{60} \mathrm{Co}$ activity in soil.

FIGURE 7. Cobalt-60 in Vegetation

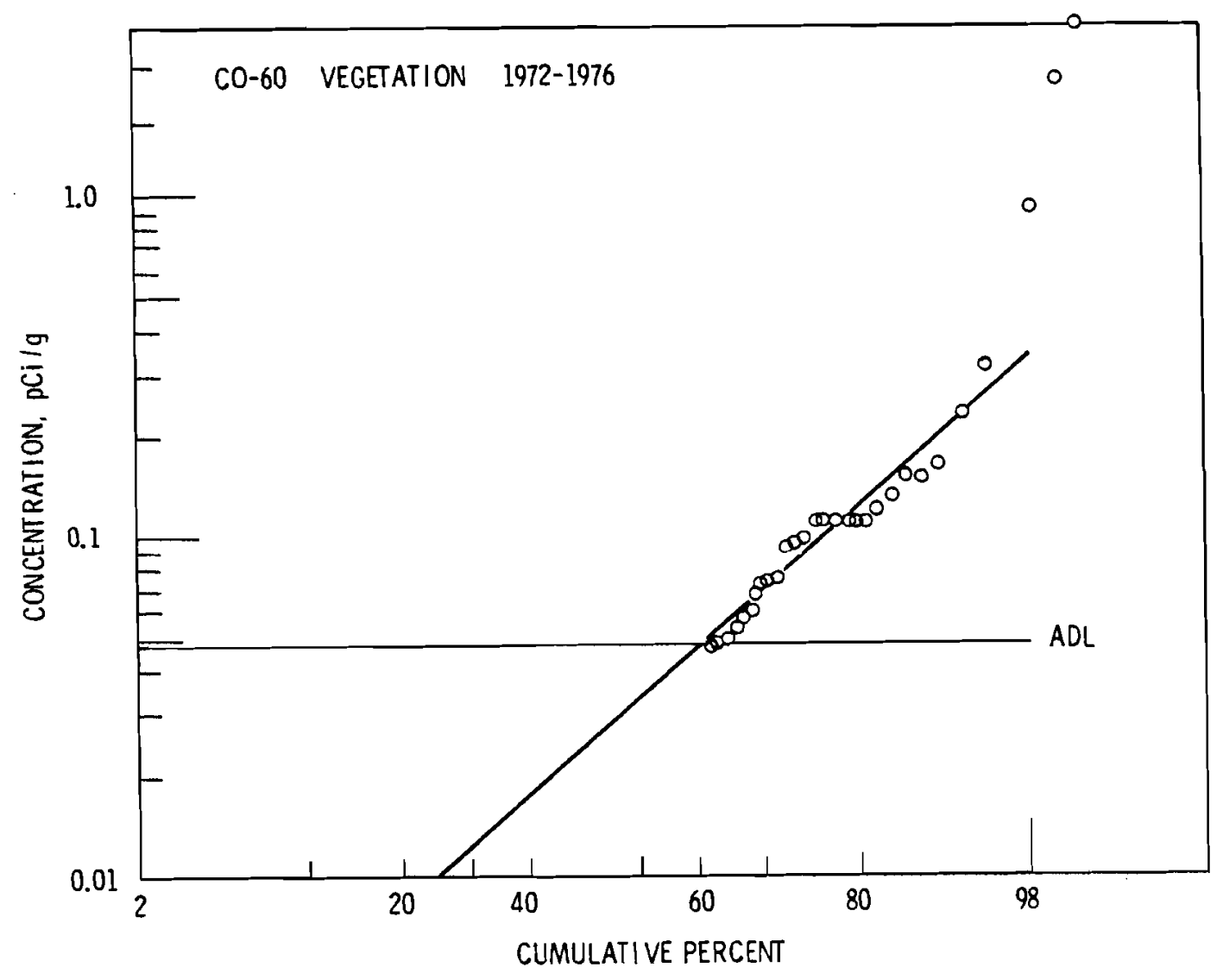


Several other radionuclides were measured in soil and vegetation samples. Appendices $A$ and $B$ contain log-normal probability plots for all of the radionuclides. Table 3 summarizes the median concentrations of the radionuclides observed in soil and vegetation.

\section{TABLE 3. Median Concentrations of Man-Made Radionuclides} in Soil and Vegetation in the Hanford Environs

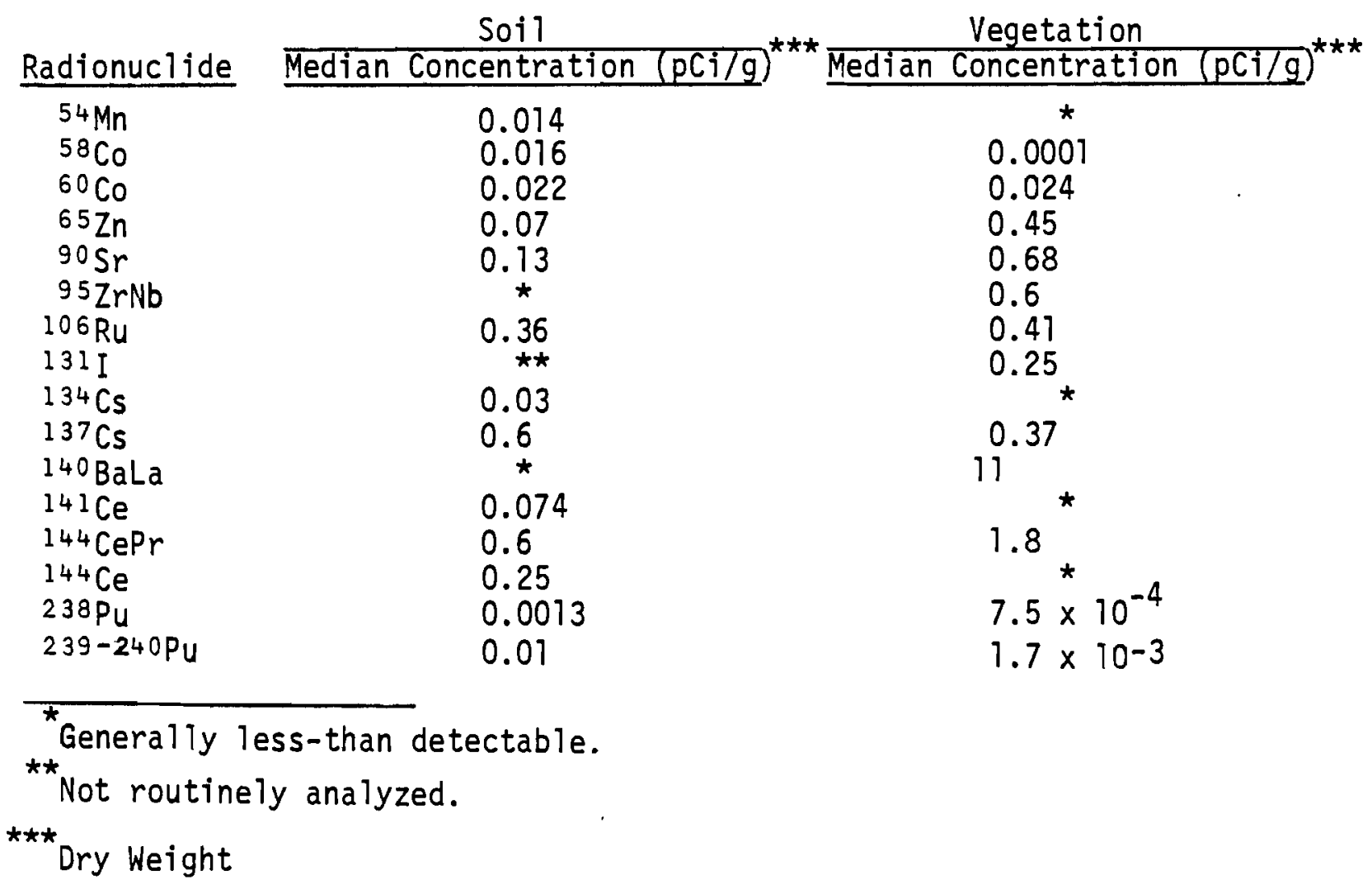




\section{ACKNOWLEDGMENTS}

The efforts of several people were necessary to collect, analyze and evaluate the extensive data acquired as part of the ERDA-sponsored Environmental Surveillance Program at Hanford. The Laboratories of U. S. Testing Company performed the analyses. Shellie Canada and Marian Goff typed the report. 


\section{REFERENCES}

1. National Council on Radiation Protection and Measurements, Natural Background Radiation in the United States, NCRP \#45, NCRP, Washington, DC, November 1975.

2. R. R. Mooney, Environmental Radiation Surveillance in Washington State. Department of Social and Health Services, Health Services Division, Olympia, Washington. Annual Reports.

3. J. J. Fix, D. R. Speer, and P. J. Blumer, Environmental Status of the Hanford Site for CY-1975, BNWL-B-477, Battelle, Pacific Northwest Laboratories, Richland, WA, 1976.

4. D. A. Waite and P. E. Bramson, Interpretation of Near Background Environmental Surveillance Data by Distribution Analysis, IAEA-SM-202/706, Battelle, Pacific Northwest Laboratories, Richland, WA 99352.

5. D. E. Michels, Log-Normal Analys is of Data for Plutonium in the Outdoors, LA-4756, Proceedings of the Environmental Piutonium Symposium Los Alamos Scientific Laboratory, Los Alamos, NM, August, 1971.

6. J. J. Fix, Association of Long-Lived Radioactivity with Sediment Along the Columbia River Shoreline, Is lands, Bottom and Slough Area, BNWL-SA5484 , Battelle, Pacific Northwest Laboratories, Richland, WA 99352 , Apri1 1976. 
APPENDIX A

LOG-NORMAL PLOTS OF RADIONUCLIDES IN SOIL 


\section{APPENDIX A}

\section{LOG-NORMAL PLOTS OF RADIONUCLIDES IN SOIL}

The following pages present log-normal probability plots for radionuclides found in soil of the Hanford environs. Only significantly-positive data were plotted, that is, data that was above the approximate detection level (ADL). The ADL is defined as the 2-sigma counting uncertainty and may vary depending on the sample mass, counting time used, or in the case of gamma spectroscopy, the interference of other radionuclides that may be present. The ADL is indicated on those plots where it was in the same range as the observed data. The plots are presented in order of increasing atomic number, with naturally-occurring and man-made radionuclides being grouped separately.

\begin{tabular}{ll}
\multicolumn{1}{r}{ Radionuclide } & Page \\
Potassium-40 & $\mathrm{A} .2$ \\
Radium-224 & $\mathrm{A} .2$ \\
Radium-226 & $\mathrm{A} .3$ \\
Uranium-Tota 1 & $\mathrm{~A} .3$ \\
Manganese-54 & $\mathrm{A} .4$ \\
Cobalt-58 & $\mathrm{A} .4$ \\
Cobalt-60 & $\mathrm{A} .5$ \\
Zinc-65 & $\mathrm{A} .5$ \\
Strontium-90 & $\mathrm{A} .6$ \\
Ruthenium-106 & $\mathrm{A} .6$ \\
Cesium-134 & $\mathrm{A} .7$ \\
Cesium-137 & $\mathrm{A} .7$ \\
Cerium-141 & $\mathrm{A} .8$ \\
Cerium-144 & $\mathrm{A} .8$ \\
Cerium-Promethium-144 & $\mathrm{A} .9$ \\
Plutonium-238 & $\mathrm{A} .9$ \\
Plutonium-239,240 & $\mathrm{A} .10$
\end{tabular}


Log-Normal Plots of Natural1y-Occurring Radionuclides
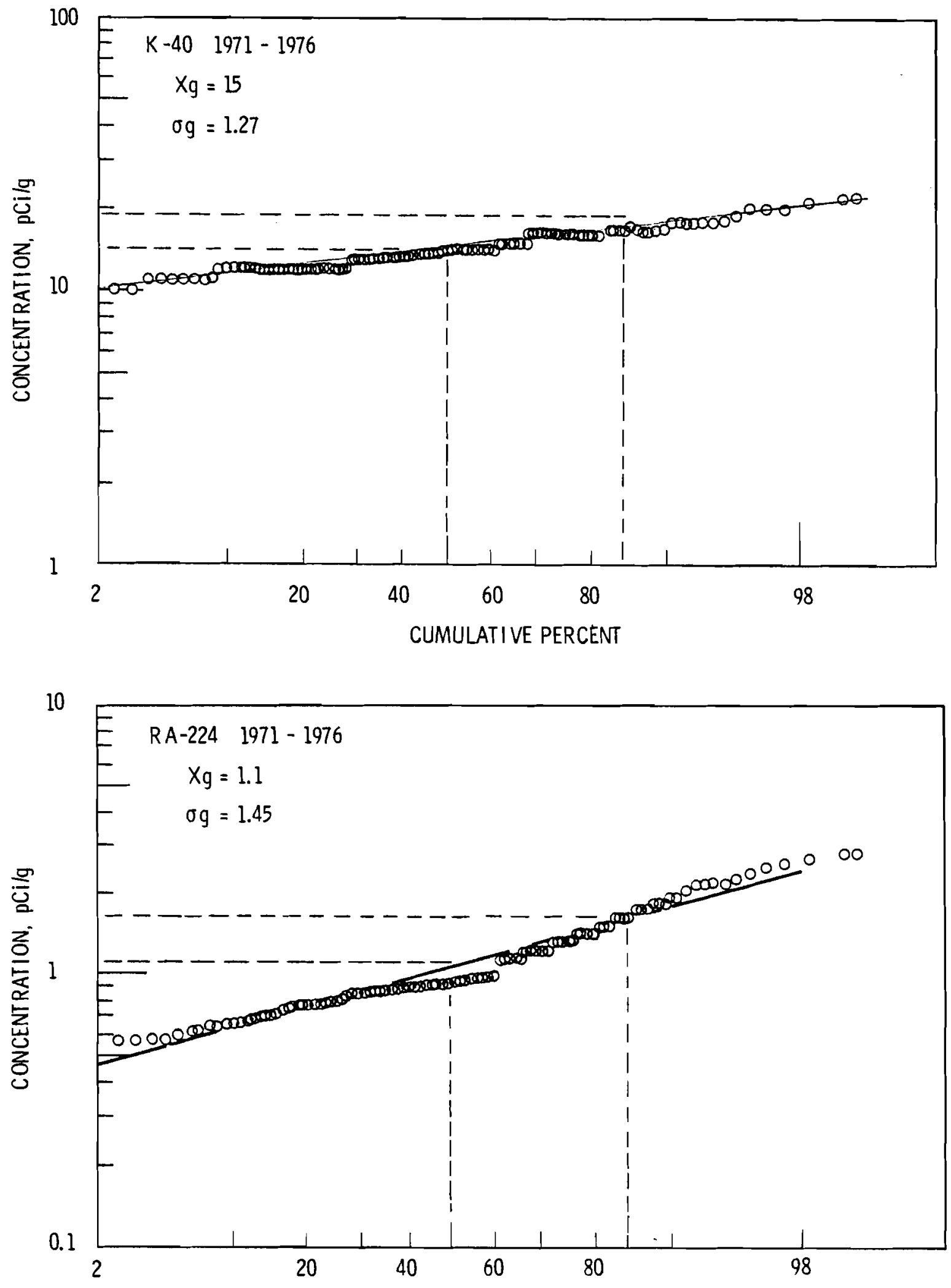
Log-Normal Plots of Naturally-Occurring Radionuclides (Cont'd.)
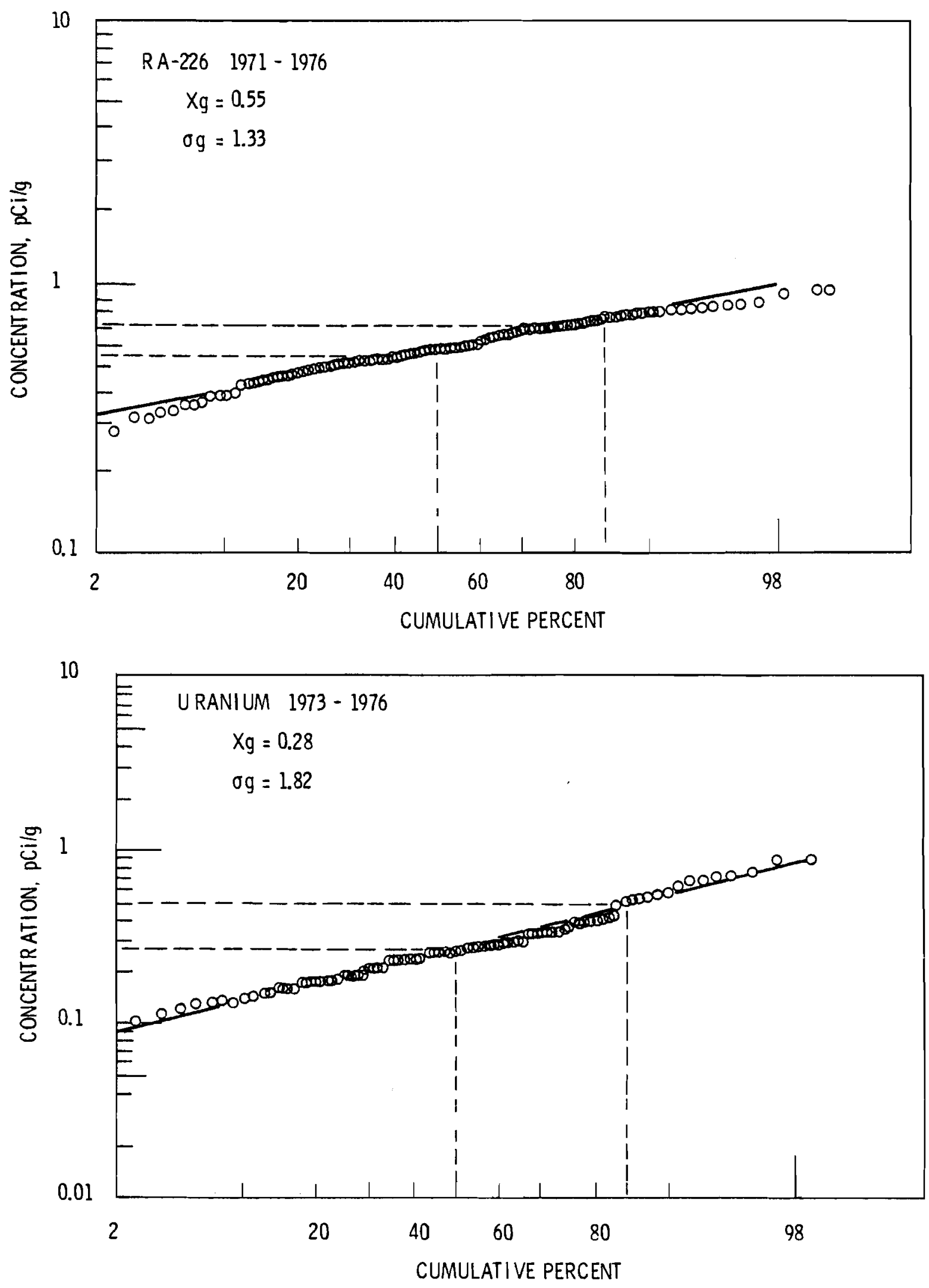


\section{Log-Normal Plots of Man-Made Radionuclides}
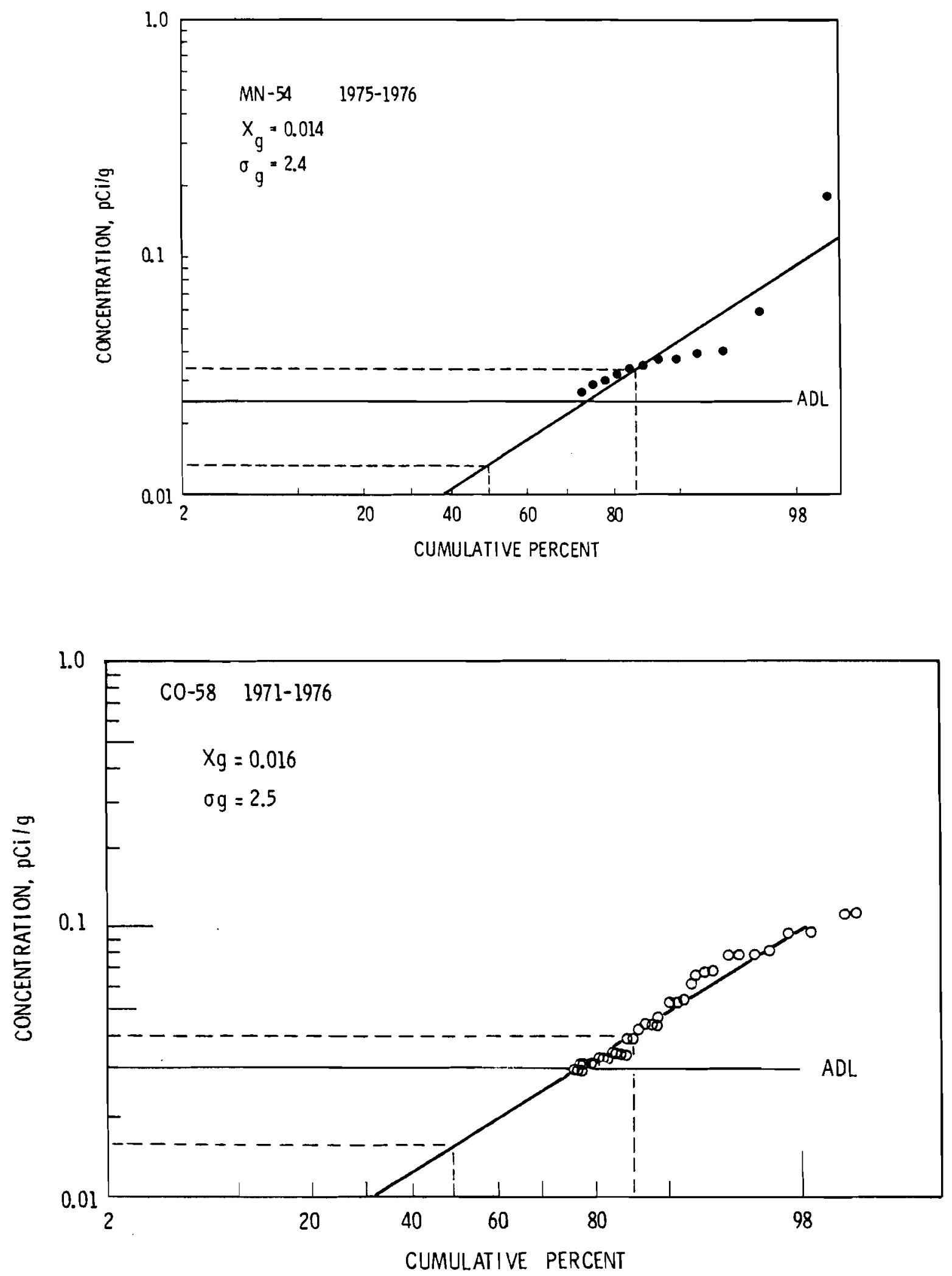

A. 4 
Log-Normal Plots of Man-Made Radionuclides (Cont'd.)
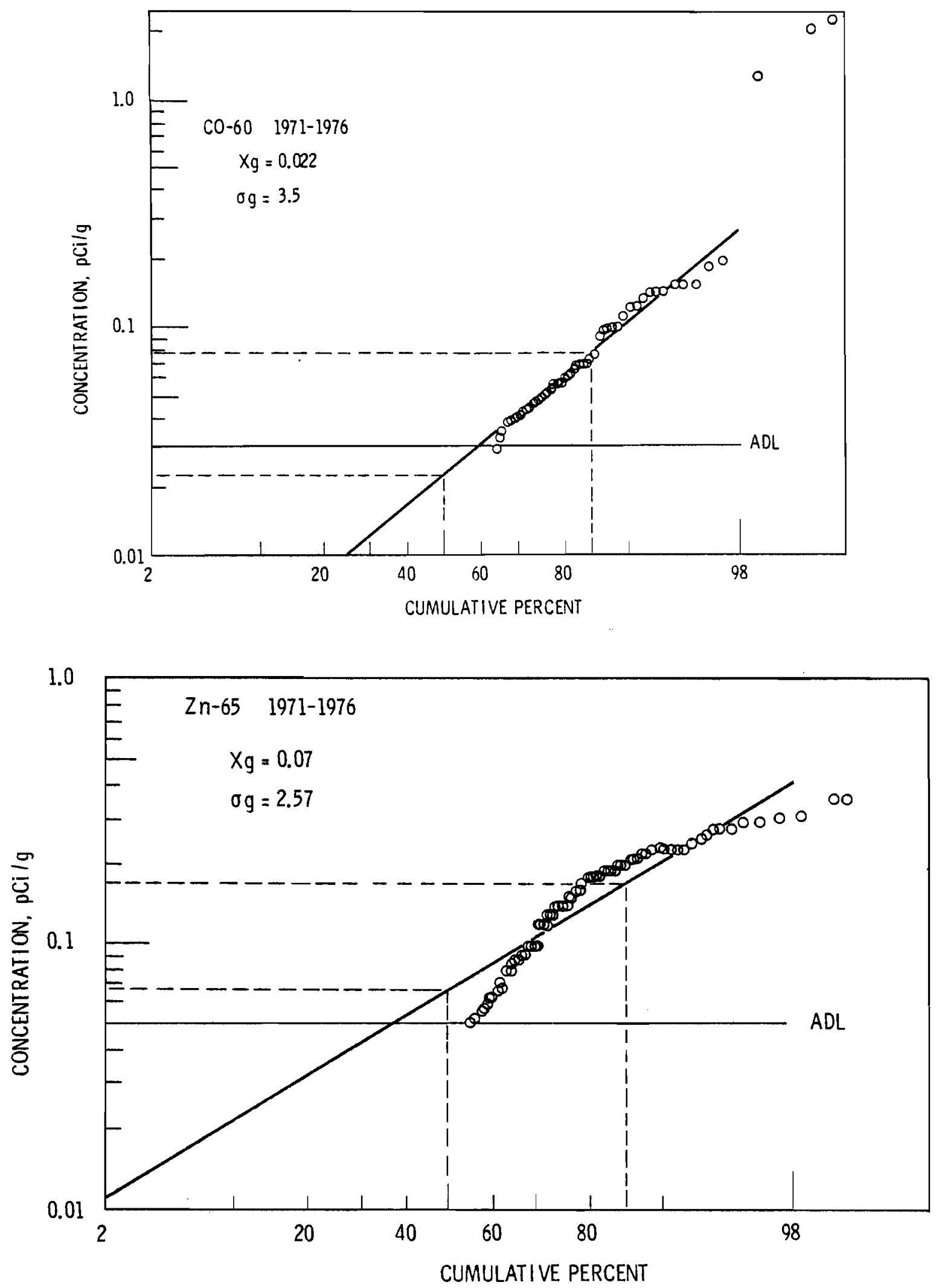

A. 5 
Log-Normal Plots of Man-Made Radionuclides (Cont'd.)
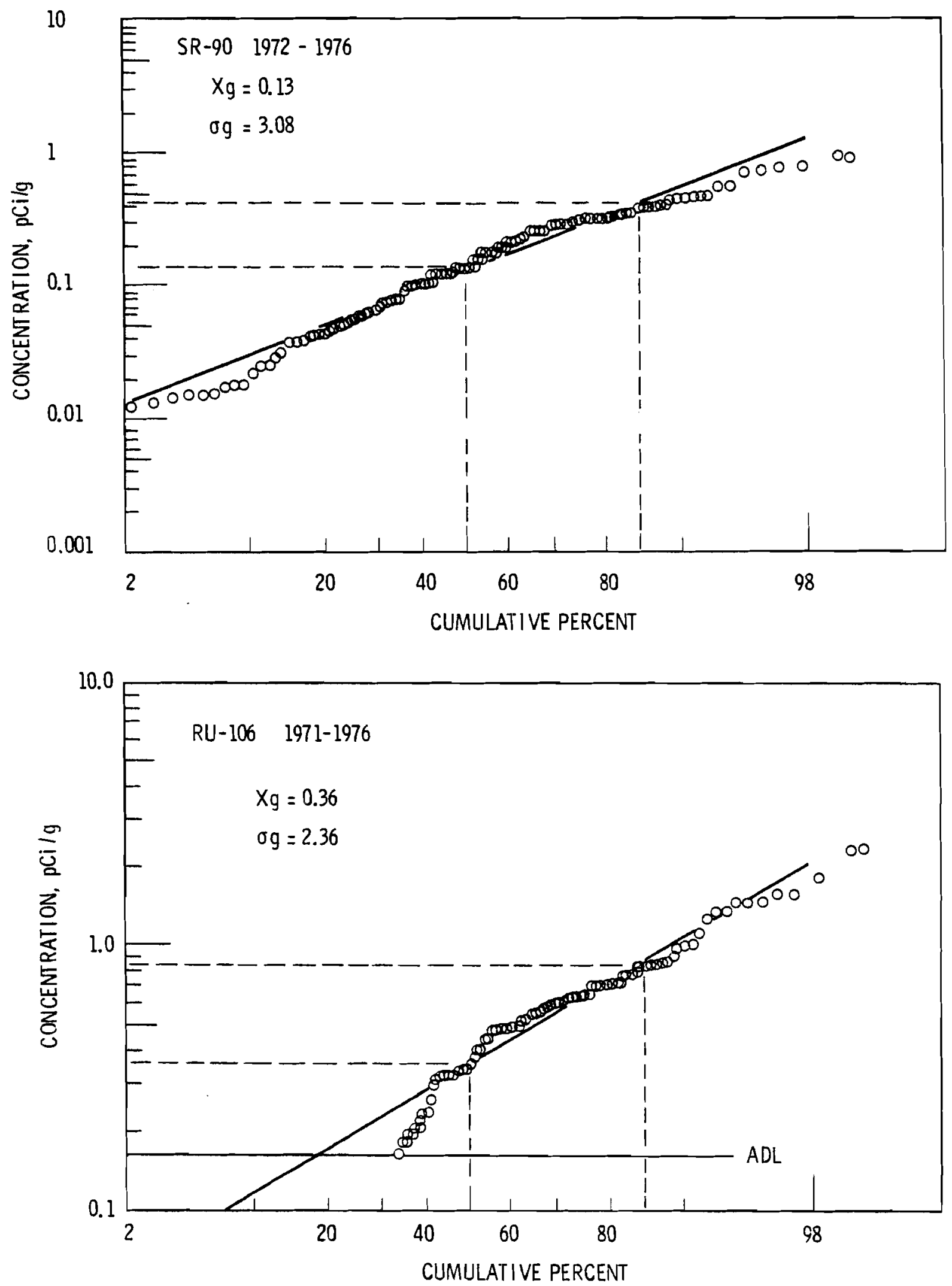

A. 6 
Log-Normal Plots of Man-Made Radionuclides (Cont'd.)
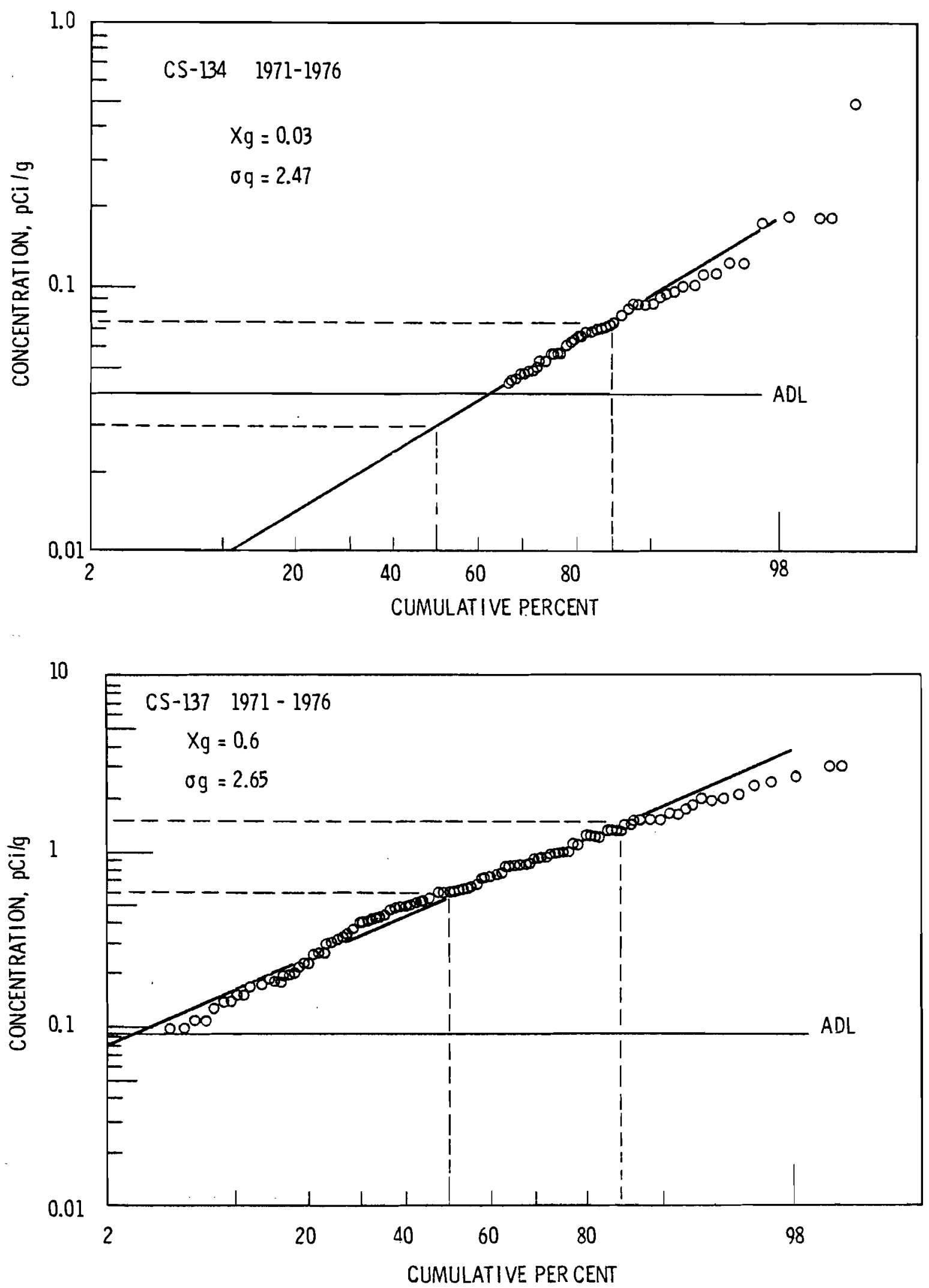


\section{Log-Normal Plots of Man-Made Radionuclides (Cont'd.)}
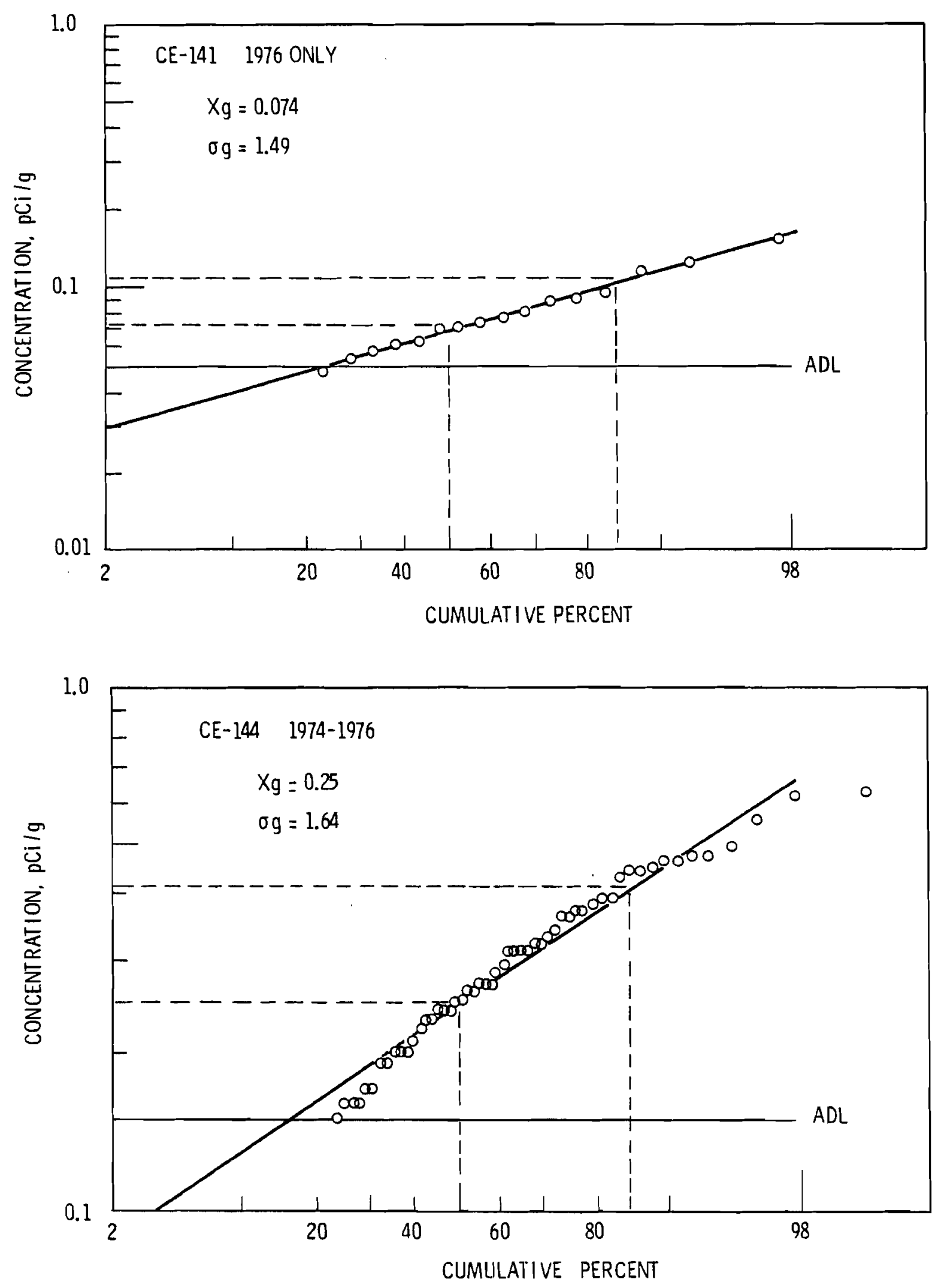

A. 8 


\section{Log-Normal Plots of Man-Made Radionuclides (Cont'd.)}
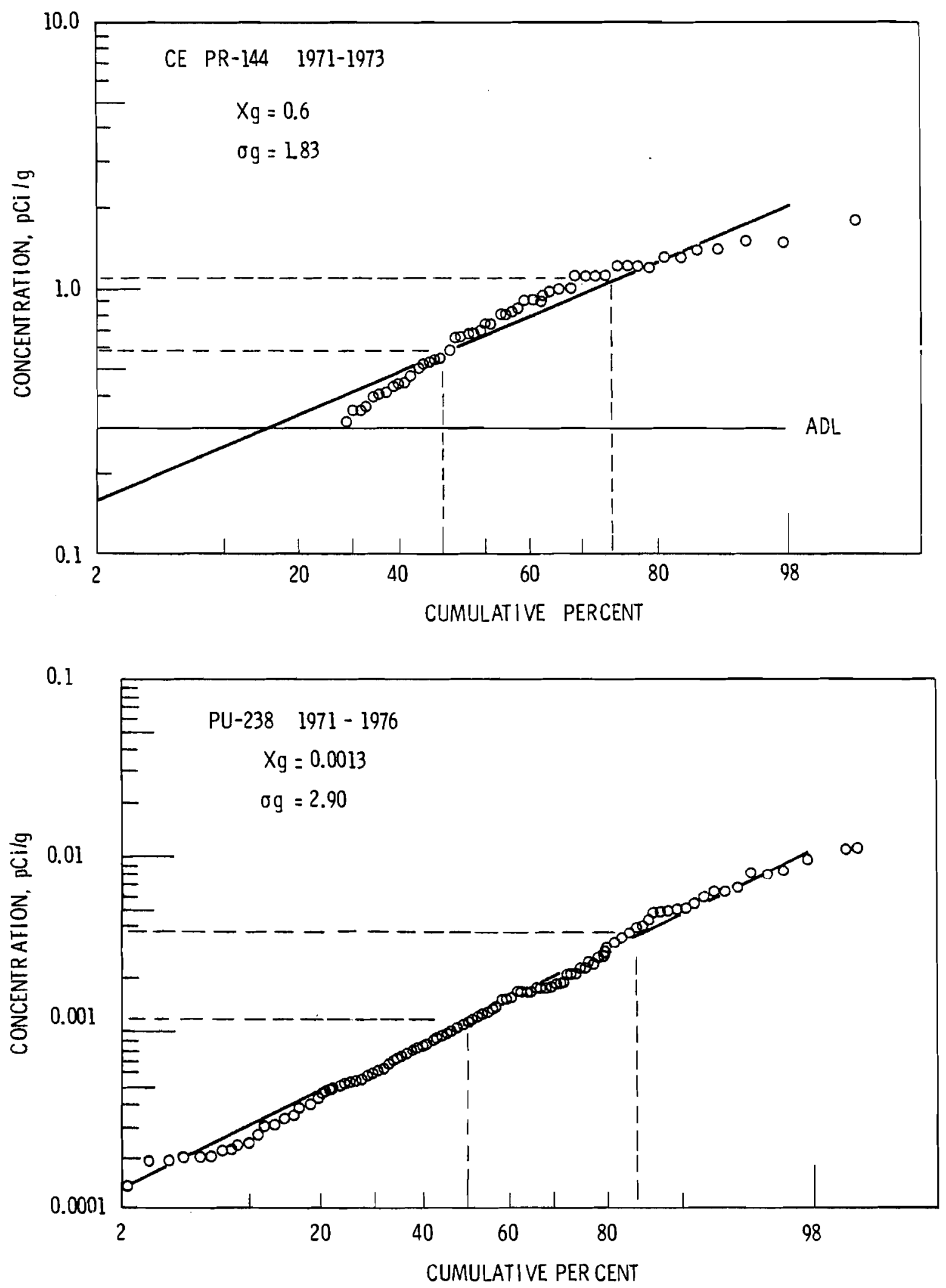


\section{Log-Normal Plots of Man-Made Radionuclides (Cont'd.)}

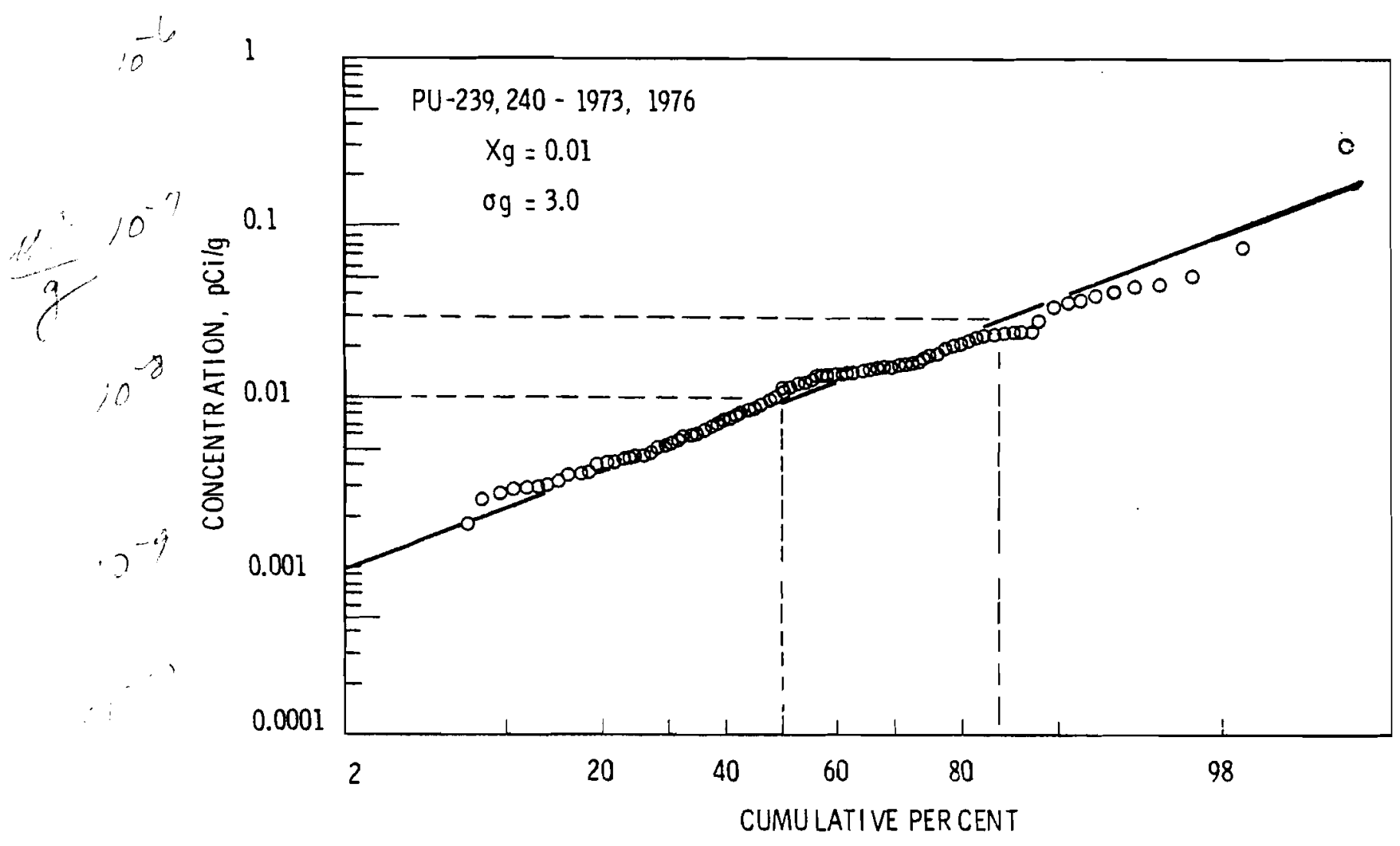

A. 10 


\section{APPENDIX B}

LOG-NORMAL PLOTS OF RADIONUCLIDES IN VEGETATION 
APPENDIX B

\section{LOG-NORMAL PLOTS OF RADIONUCLIDES IN VEGETATION}

The following pages present log-normal probability plots for radionuclides found in vegetation of the Hanford environs. Only significantlypositive data were plotted, that is, data that was above approximate detection leve1 ( $A D L)$. The ADL is defined as the 2-sigma counting uncertainty and may vary depending on the sample mass, counting time used, or in the case of gamma spectroscopy, the interference of other radionuclides that may be present. The ADL is indicated on those plots where it was in the same range as the observed data. The plots are presented in order of increasing atomic number with naturally-occurring and man-made radionuclides being grouped separately.

\begin{tabular}{lc}
\multicolumn{1}{c}{ Radionuclide } & Page \\
Potassium-40 & B.2 \\
Uranium-Tota 1 & B.2 \\
Cobalt-60 & B.3 \\
Zinc-65 & B.3 \\
Strontium-90 & B.4 \\
Zirconium-Niobium-95 & B.4 \\
Ruthenium-106 & B.5 \\
Iodine-131 & B.5 \\
Cesium-137 & B.6 \\
Barium-Lanthanum-140 & B.6 \\
Cerium-Promethium-144 & B.7 \\
Plutonium-238 & B.7 \\
Plutonium-239,240 & B.8
\end{tabular}




\section{Log-Normal Plots of Naturally-Occurring Radionuclides}
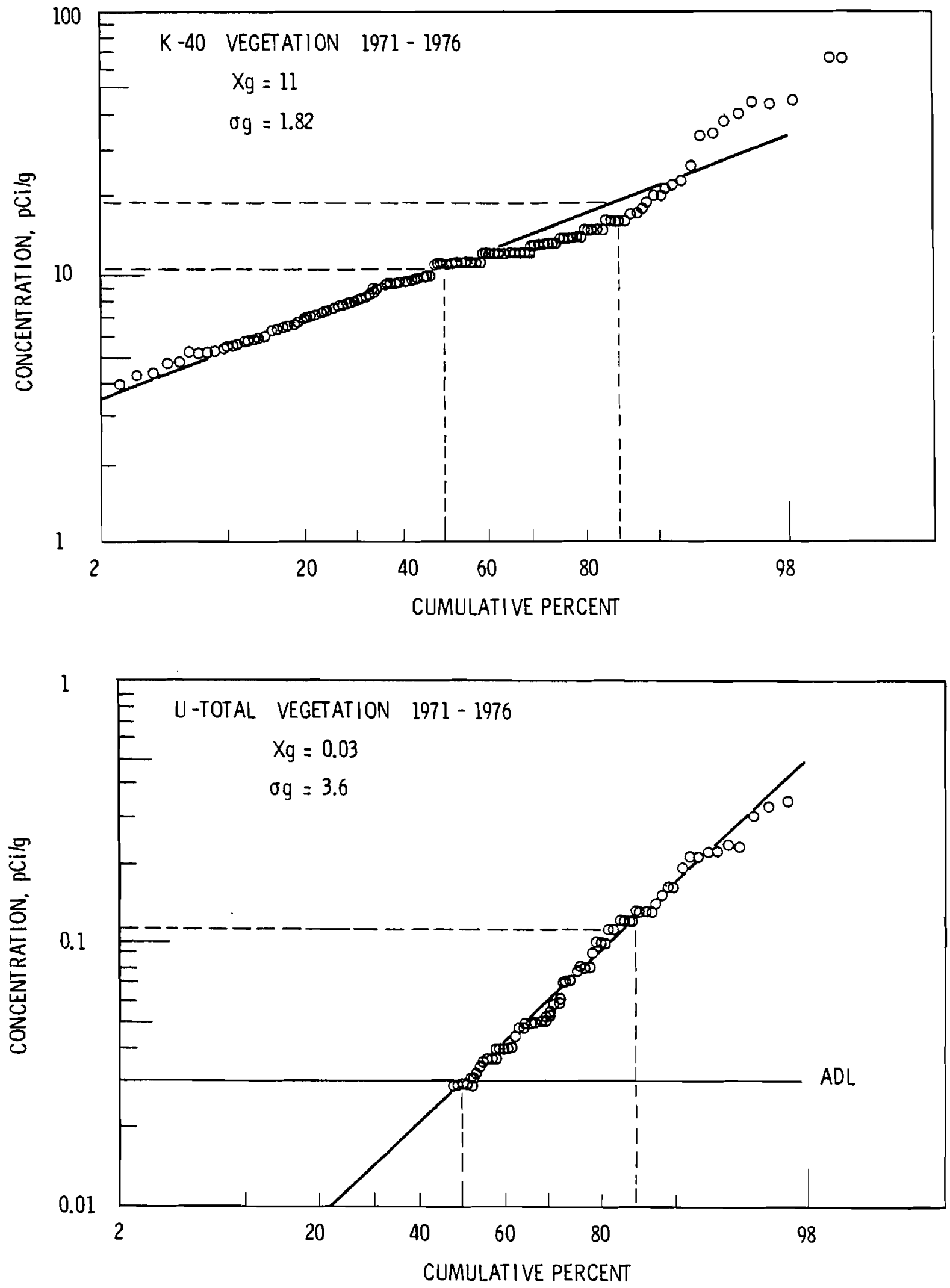

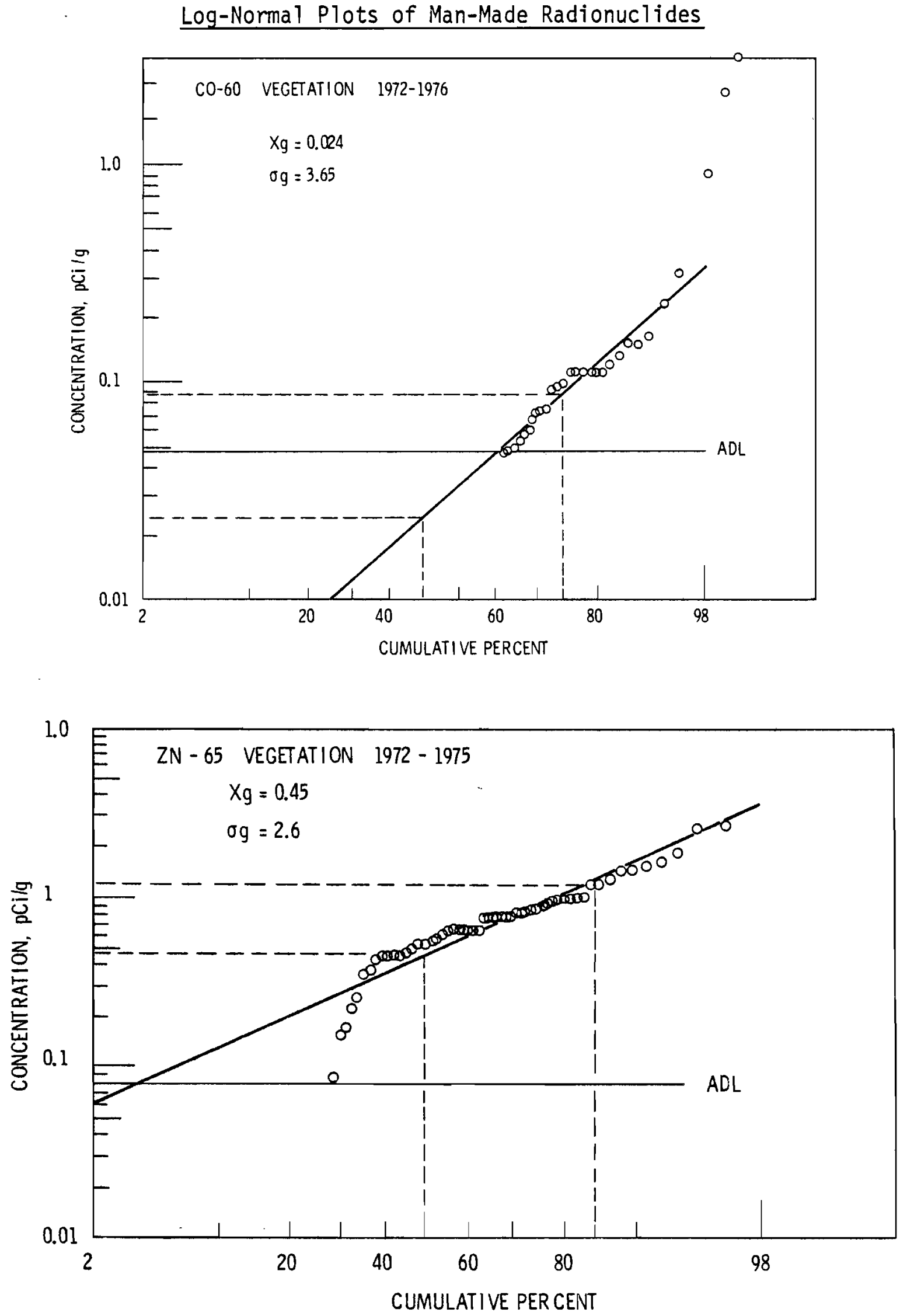

B. 3 
Log-Normal Plots of Man-Made Radionuclides (Cont'd.)
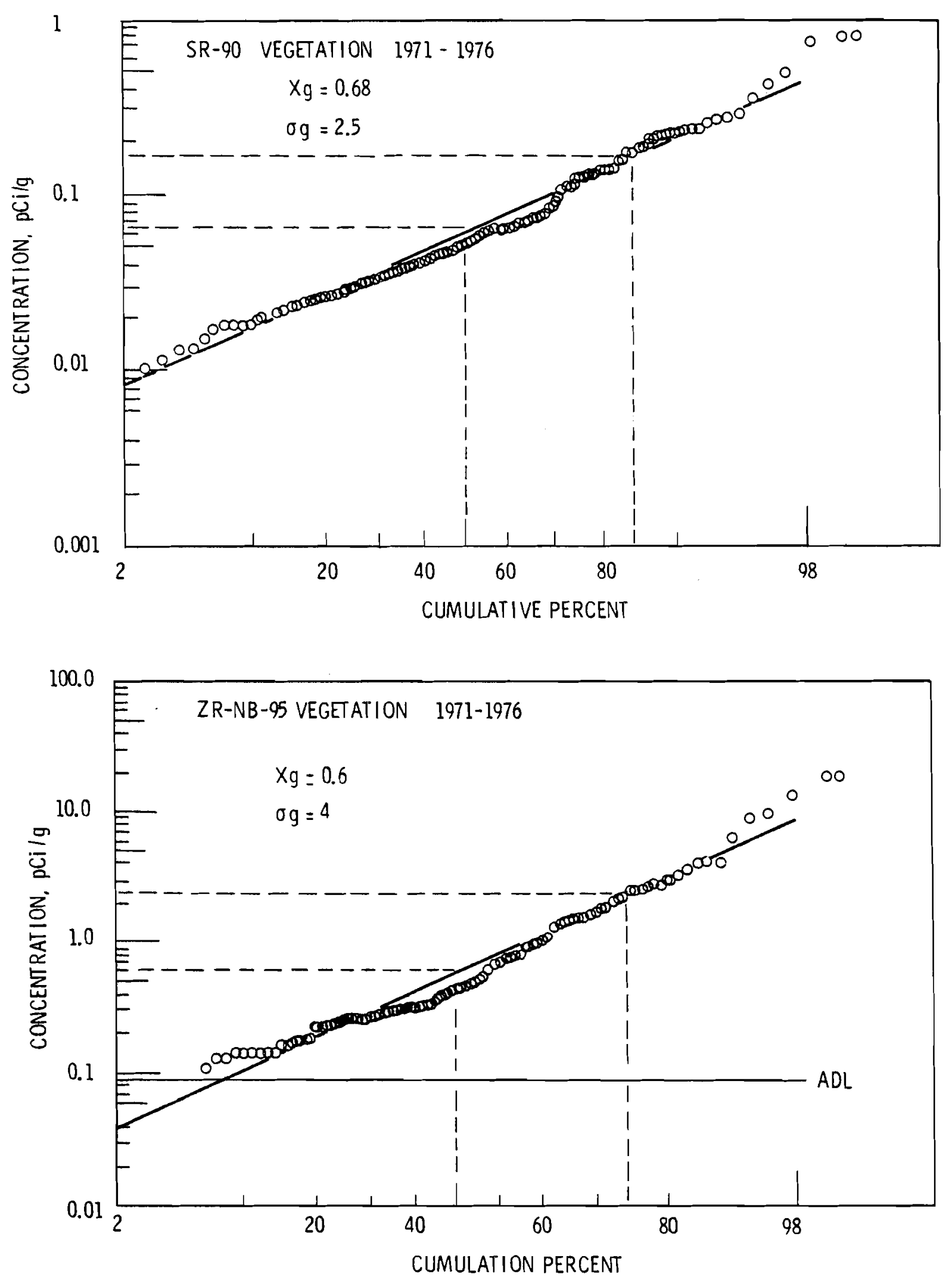

B. 4 
Log-Normal Plots of Man-Made Radionuclides (Cont'd.)
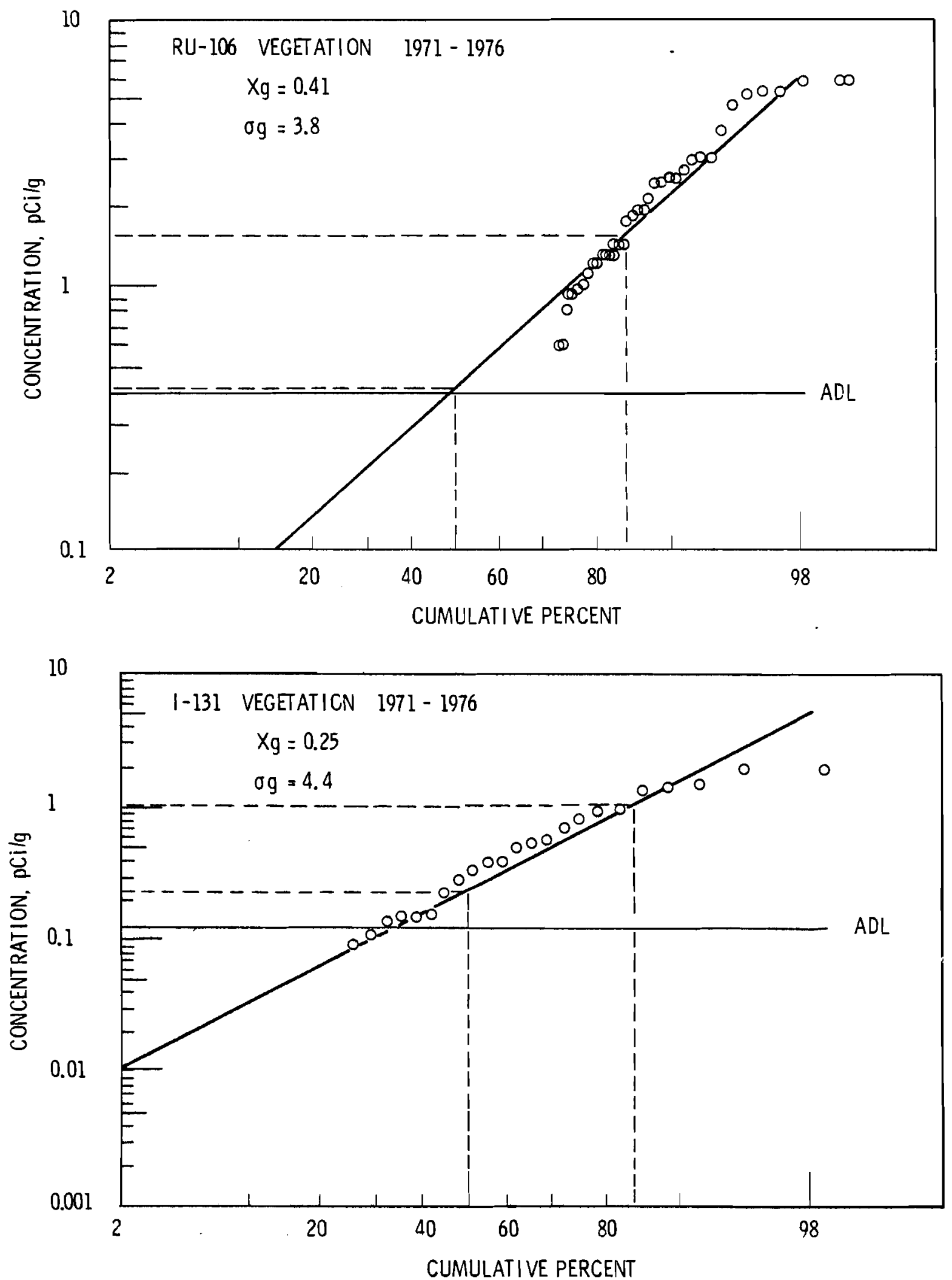

B. 5 

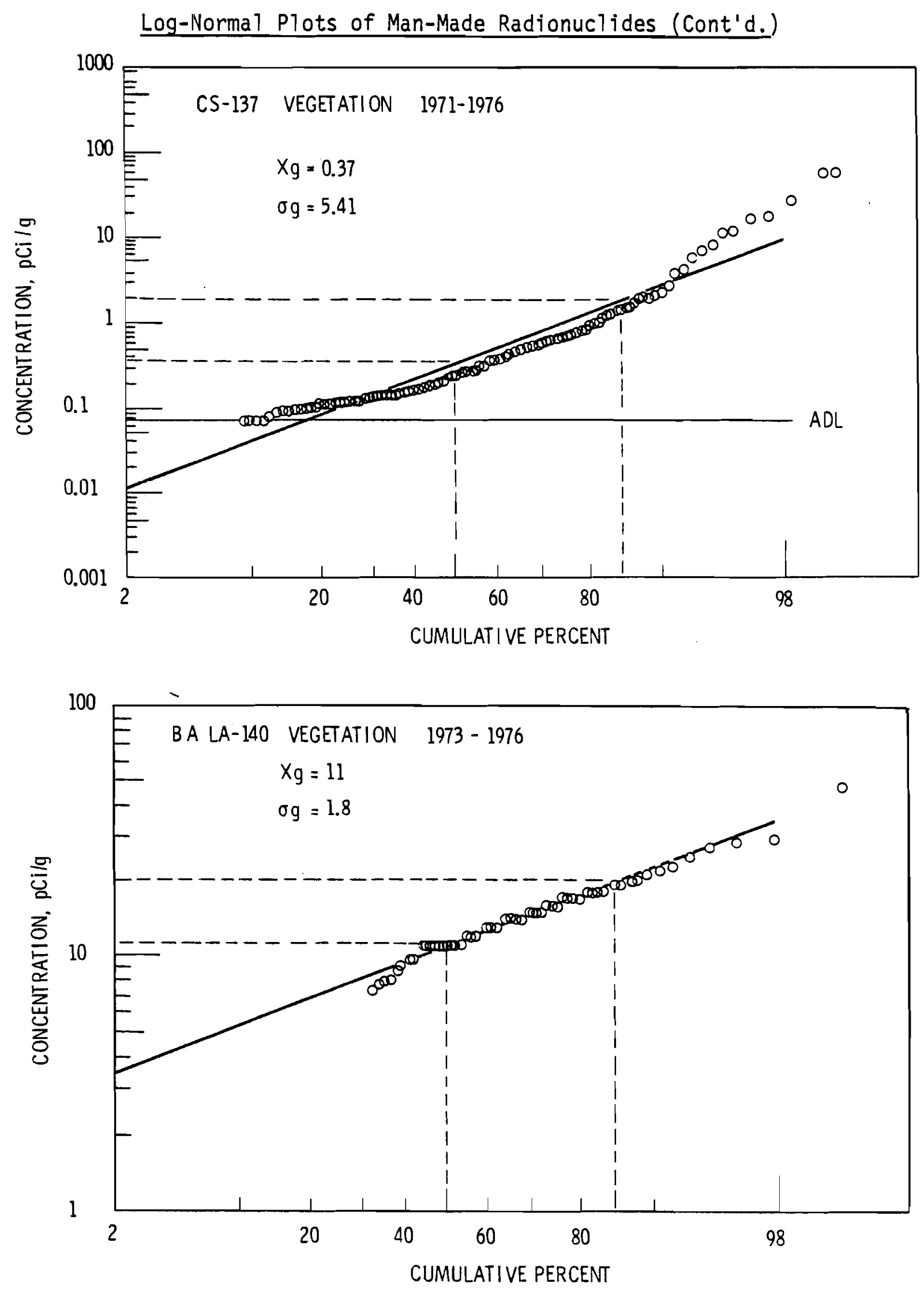

B. 6 


\section{Log-Normal Plots of Man-Made Radionuclides (Cont'd.)}
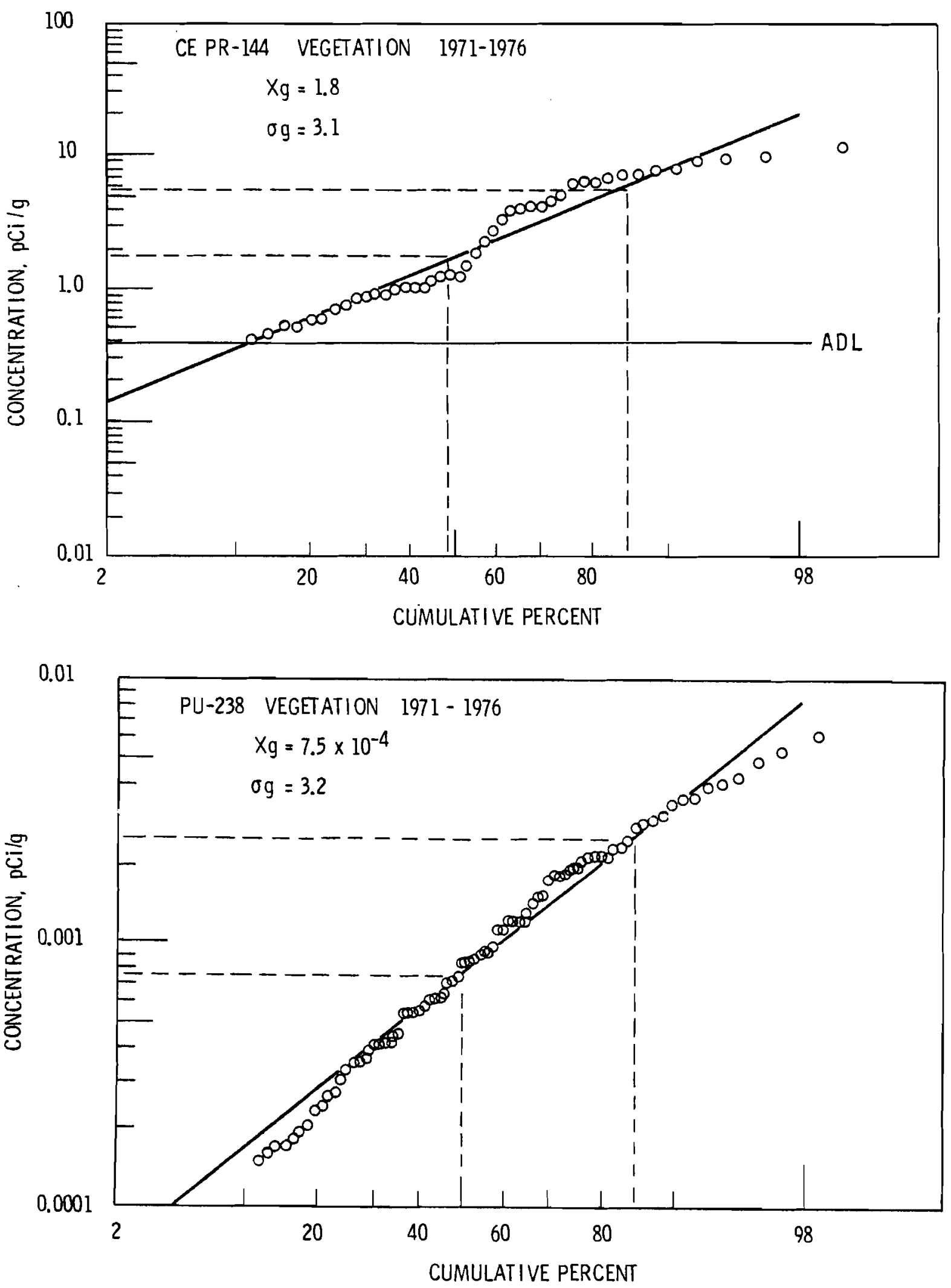
Log-Normal Plots of Man-Made Radionuclides (Cont'd.)

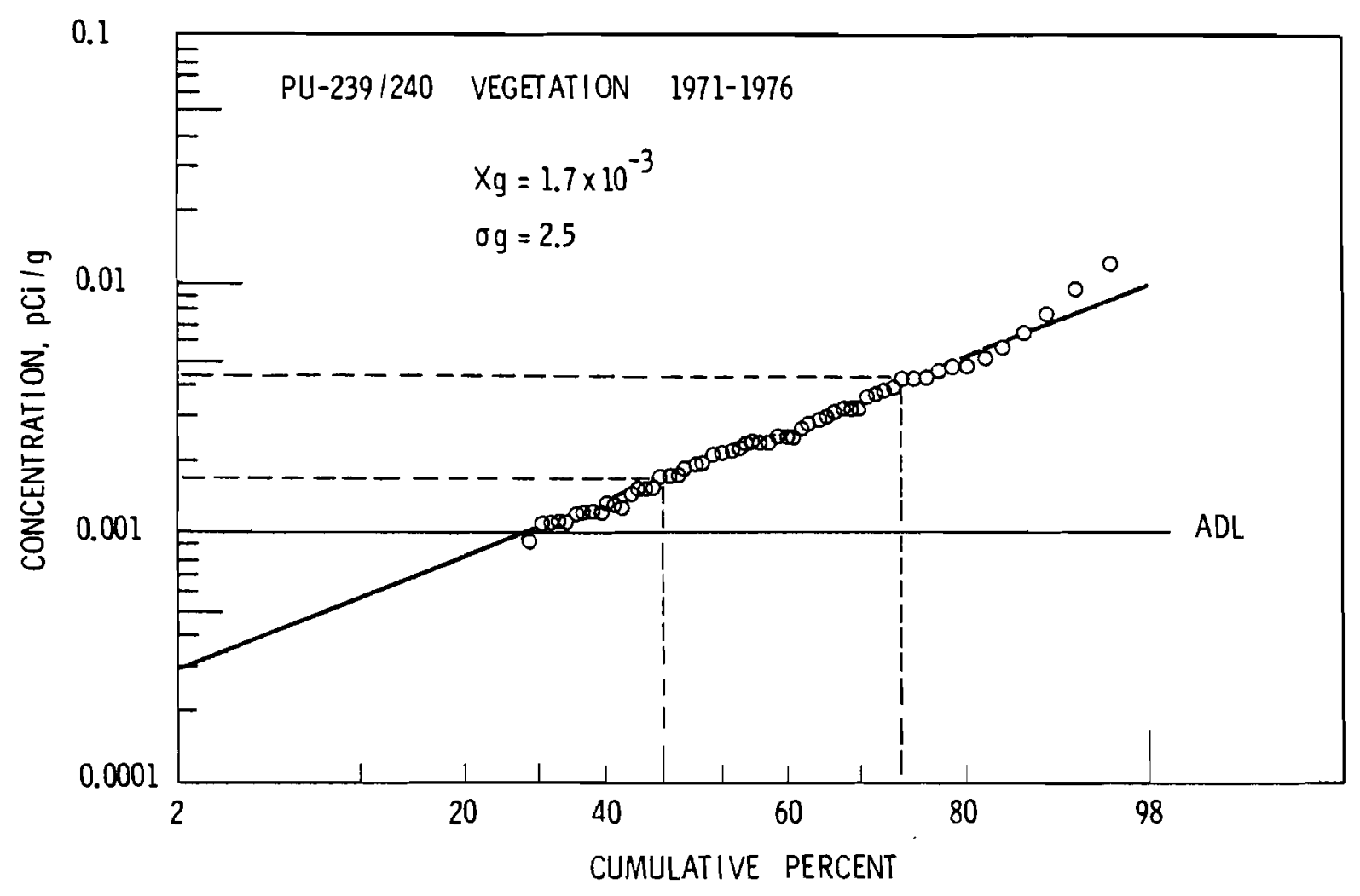

B. 8 
APPENDIX C

MECHANICS OF LOG-NORMAL PLOTTING 


\section{MECHANICS OF LOG-NORMAL PLOTTING}

To illustrate the mechanics of log-normal plotting, an example from Appendix $A,{ }^{134} \mathrm{Cs}$ in soil, will be processed in a stepwise manner so that the technique will be clearly described and more understandable. It should be understood that there is nothing exotic or special about log-normal plotting. It is merely a tool, a graphical tool, that experience has shown to be a good and useful first approach to the problem of environmental data analysis. Logically, we cannot prove that a given transformation is proper, but we can show when a particular transformation is adequate. (5)

An important element of this kind of data analysis is to treat the data as groups, not as individuals. Al1 meaning comes from the relationship among values. Thus, distributions are the primary objects to be described. Statistical validity in plotting requires that samples be combined into homogeneous groups. (Members of a homogeneous group can be collectively described by a single mean value and standard deviation). (4)

To construct a log-normal plot the raw (random) data are arranged in order from largest to smallest (see Table 1C). Table $1 C$ shows typical data including several negative values, zeros and all positive numbers near an approximate detection level (ADL) of $0.04 \mathrm{pCi} / \mathrm{g}$. This detection limit for gamma spectrometric analys is of ${ }^{134} \mathrm{Cs}$ varies depending on the counting time used, the types and quantities of other radionuclides present and the mass of the sample. Although the 2-sigma counting error is reported for all analytical results since mid-1975, the earlier results of this study did not include the uncertainty factor for individual measurements, thus making the evaluation of some data more difficult. Also, analytical techniques have improved over the years, effectively lowering the ADL.

The second step is to calculate the cumulative percent of each sample, $X i$, using the formula:

$$
x_{i}=100(N-i+0.5) / N
$$

where $n$ is the population size and $i$ is the individual data rank. The data are now ready to be plotted on log probability graph paper (Figure $1 C$ ). 
TABLE 1C. Typical Analytical Data

\begin{tabular}{|c|c|c|c|c|c|}
\hline $\begin{array}{l}\text { Data } \\
\text { Rank (a) }\end{array}$ & $\begin{array}{l}\text { Analytical } \\
\text { Results(b) } \\
\mathrm{pCi} / \mathrm{g} \\
\end{array}$ & $\begin{array}{l}\text { Data }(a) \\
\text { Rank }\end{array}$ & $\begin{array}{l}\text { Analytical } \\
\text { Results (b) } \\
\mathrm{pCi} / \mathrm{g} \\
\end{array}$ & $\begin{array}{l}\text { Data }(a) \\
\text { Rank }\end{array}$ & $\begin{array}{c}\text { Analytical } \\
\text { Results }(b) \\
\mathrm{pCi} / \mathrm{g}\end{array}$ \\
\hline 1 & 0.47 & 38 & 0.049 & 75 & 0.022 \\
\hline 2 & 0.18 & 39 & 0.048 & 76 & 0.019 \\
\hline 3 & 0.18 & 40 & 0.047 & 77 & 0.019 \\
\hline 4 & 0.17 & 41 & 0.047 & 78 & 0.019 \\
\hline 5 & 0.12 & 42 & 0.046 & 79 & 0.018 \\
\hline 6 & 0.12 & 43 & 0.046 & 80 & 0.017 \\
\hline 7 & 0.11 & 44 & 0.044 & 81 & 0.017 \\
\hline 8 & 0.11 & 45 & 0.044 & 82 & 0.016 \\
\hline 9 & 0.10 & 46 & 0.043 & 83 & 0.016 \\
\hline 10 & 0.098 & 47 & 0.042 & 84 & 0.015 \\
\hline 11 & 0.095 & 48 & 0.041 & 85 & 0.012 \\
\hline 12 & 0.093 & 49 & 0.040 & 86 & 0.011 \\
\hline 13 & 0.090 & 50 & 0.039 & 87 & 0.0092 \\
\hline 14 & 0.086 & 51 & 0.038 & 88 & 0.0090 \\
\hline 15 & 0.084 & 52 & 0.038 & 89 & 0.0079 \\
\hline 16 & 0.084 & 53 & 0.036 & 90 & 0.0077 \\
\hline 17 & 0.084 & 54 & 0.036 & 91 & 0.0075 \\
\hline 18 & 0.081 & 55 & 0.035 & 92 & 0.0069 \\
\hline 19 & 0.077 & 56 & 0.035 & 93 & 0.0063 \\
\hline 20 & 0.072 & 57 & 0.034 & 94 & 0.0060 \\
\hline 21 & 0.071 & 58 & 0.034 & 95 & 0.0058 \\
\hline 22 & 0.069 & 59 & 0.030 & 96 & 0.0031 \\
\hline 23 & 0.068 & 60 & 0.030 & 97 & 0.0030 \\
\hline 24 & 0.068 & 61 & 0.030 & 98 & 0.0029 \\
\hline 25 & 0.067 & 62 & 0.030 & 99 & 0.0026 \\
\hline 26 & 0.067 & 63 & 0.030 & 100 & 0.00063 \\
\hline 27 & 0.064 & 64 & 0.030 & $101-129$ & \\
\hline 28 & 0.064 & 65 & 0.029 & 130 & -0.0026 \\
\hline $\begin{array}{l}29 \\
30\end{array}$ & 0.062 & 66 & 0.028 & 131 & -0.0028 \\
\hline $\begin{array}{l}30 \\
31\end{array}$ & 0.061 & 67 & 0.028 & $\begin{array}{l}132 \\
133\end{array}$ & -0.0058 \\
\hline 32 & 0.056 & $\begin{array}{l}00 \\
69\end{array}$ & $\begin{array}{l}0.026 \\
0.026\end{array}$ & 134 & $\begin{array}{l}-0.0064 \\
-0.0073\end{array}$ \\
\hline 33 & 0.055 & 70 & 0.026 & 135 & -0.0075 \\
\hline 34 & 0.055 & 71 & 0.024 & 136 & -0.0081 \\
\hline 35 & 0.055 & 72 & 0.022 & 137 & -0.0089 \\
\hline 36 & 0. & 73 & 0.022 & 138 & -0.013 \\
\hline 37 & 0. & 74 & 0.022 & 139 & -0.026 \\
\hline
\end{tabular}

\footnotetext{
(a) The randomly organized data received from the field were ranked to show their range and the inclusion of negative values.

(b) Zero or negative numbers result from attempting to determine individual sample count rate relative to the expected background count rate.
} 
FIGURE 1C. Log-Normal Plot of ${ }^{134}$ Cs Data

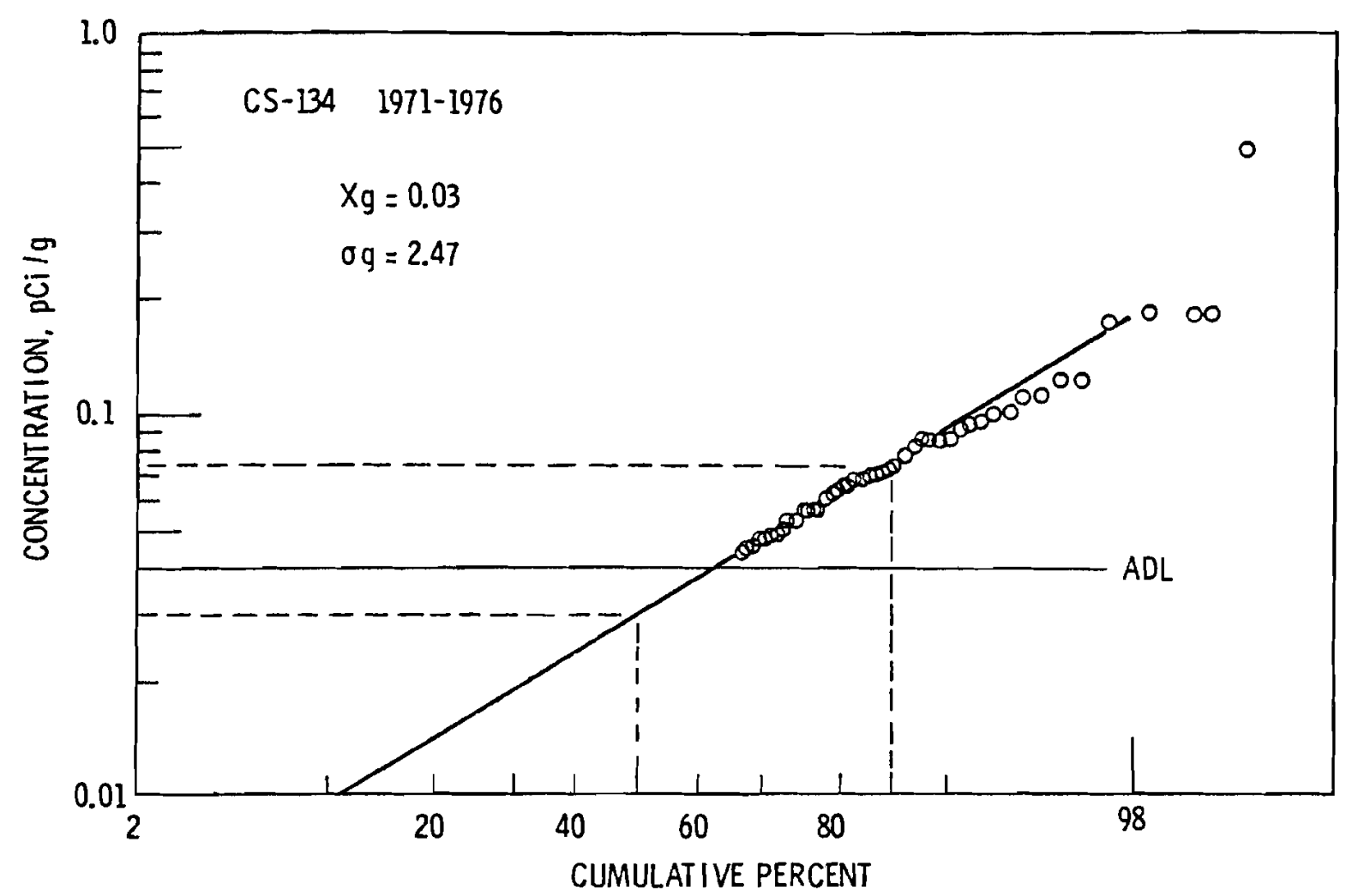

Only data which lies above the ADL is plotted. Less-than detectable values nonetheless have an effect on the plot because they are included in the total $\mathrm{N}$. In ranking the data, all values are considered in assigning position (cumulative percent). Therefore, the presence of many less-than values will cause a shift to the right on the abscissa (probability). This will directly effect the geometric mean $\left(x_{g}\right)$, which is the $50 \%$ intercept.

When data are plotted on probability paper, a straight line through the data will yield values for the geometric mean $x_{g}$ and the standard geometric mean, $\sigma_{g}$; the geometric mean is given by the fiftieth cumulative percent intercept, while the $\sigma_{g}$ is obtained by the "slope" of the line or as the ratio of the 84 and 50 cumulative percent intercepts. (4) For Figure $1 C$, the $x_{g}$ is 0.03 and the $\sigma_{g}$ is 2.47. Experience has shown that a wide range of $x_{g} s$ and $\sigma_{g} s$ are possible for plots of environmental surveillance data. 
The geometric mean, $x_{g}$, is really the median value of the population sampled. In environmental applications it can often be used as the "expected value" in lieu of the arithmetic mean. In many situations this proves more useful because its value is not skewed by large values at the upper end of the population distribution. Although it was not used in this report, a value for the derived arithmetic mean can be obtained using the formula:

$$
x_{a}=x_{g} \exp \frac{\left(n^{2} \sigma_{g}\right)}{2}
$$

The standard geometric deviation, $\sigma_{g}$, is an indicator of the range or closeness of invividual data points. A $\sigma_{g}$ equal to 1 would imply that all data points had the same value. Homogeneity of a population (linear plot) is necessary if $\sigma_{g}$ is to have much significance. The usual test for homogeneity is the data's goodness of fit to a straight line.

The majority of the plotted points shown in Figure $1 C$ approximate a straight line, indicating that these data represent samples from the same population. However, the largest value plotted in Figure $1 \mathrm{C}, 0.47 \mathrm{pCi} / \mathrm{g}$, is apparently greater than would be expected from the data collected everywhere else. Investigation showed that this sample was taken in October 1975 from the NE corner of the 100-N Area. This elevated concentration can be attributed in part to operations at the 100-N Reactor for several reasons:

1. The point does not lie on the fitted line of the plot, implying that the concentration observed is greater than would be expected from fallout.

2. Other radionuclides, such as ${ }^{54} \mathrm{Mn}$ and ${ }^{60} \mathrm{Co}$, were also observed at elevated concentrations at this sampling location.

3. The location is a likely area to be impacted by the 1301-N Trench.

Similar logic can be applied in interpreting other plots. In some instances, enough sample locations can seemingly be impacted by more than one 
source, or excessively by one particular source. In such cases it may be possible to separate a plotted population into two separate populations and replot them to determine the expected distribution of background concentrations if there is sufficient justification to show that the higher values are not a part of the background distribution. Generally, values which are above the $95 \%$ probability intercept are good candidates for further inspection, especially if they lie above the fitted line. This number also provides a comparison for any new incoming data, since only $5 \%$ are expected to be greater than this value. 


\section{DISTRIBUTION}

No. of

Copies

OFFSITE

A. A. Churm

ERDA Patent Group

U. S. Energy Research and Development Administration 9800 South Cass Avenue

Argonne, IL 60439

27 USERDA Technical Information Center

1 R. A. Chitwood Washington Public Power Supply Company 3000 George Washington Way Richland, WA 99352

1 R. K. Woodruff Washington Public Power Supply Company 3000 George Washington Way Richland, WA 99352

ONSITE

6

Atlantic Richfield Hanford Co.
G. E. Backman
G. L. Hanson
J. V. Panesko
K. R. Price
A. T. White
ARHCO Files

10 Energy Research and Development Adminis tration Richland Operations Office Environmental Affairs
O. J. Elgert
H. E. Ransom
P. G. Rhoades
F. R. Standerfer
M. W. Tiernan (6)

No. of

Copies

ONSITE (Cont'd.)

1 Hanford Environmental Health Foundation

R. G. Anderson

3 United Nuclear Industries, Inc.

T. E. Dabrowski

A. E. Engler UNI Files

3 Westinghouse Hanford Co.
R. Belanger
G. D. Carpenter
R. B. Hall

47 Battelle-Northwest

P. J. Blumer

P. E. Bramson

J. P. Corley

J. J. Fix

R. F. Foster

J. J. Fuquay

J. J. Jech

H. V. Larson

T. J. McLaughlin

M. L. Miller (21)

D. A. Myers

W. H. Rickard

G. R. Schreckhise

R. C. Schrotke (6)

J. M. Selby

J. H. Soehniein

J. K. Soldat

C. M. Unruh

D. A. Waite

Technical Information (2)

Technical Pubiications 